\title{
Structural Transition, Function and Dysfunction of TDP-43 in Neurodegenerative Diseases
}

\author{
Tariq Afroz ${ }^{\text {ab }}$, Manuela Pérez-Berlanga ${ }^{\mathrm{a}}$, and Magdalini Polymenidou ${ }^{* a}$
}

\begin{abstract}
Altered cellular localization and pathologic aggregation of RNA binding proteins (RPBs) containing low complexity regions (LCRs) is a hallmark of neurodegenerative diseases such as amyotrophic lateral sclerosis (ALS) and frontotemporal dementia (FTD). Given the importance of RBPs in maintaining a healthy RNA homeostasis, a common mechanism in disease progression is the loss of RNA-related cellular functions. In this review, we summarize and discuss the knowledge gained in the recent years on the molecular mechanisms of TDP-43 proteinopathies that comprise a set of neurodegenerative diseases characterized by the mislocalization and aggregation of the RNA-binding protein TDP-43. Based on biophysical, biochemical and in vivo data, we highlight pathways that are misregulated early in disease and contribute to its progression, thereby representing attractive therapeutic targets.
\end{abstract}

Keywords: ALS · FTD · Neurodegenerative diseases · Protein misfolding · Protein aggregation · RNA metabolism $\cdot$ TDP-43 $\cdot$ TDP-43 proteinopathies

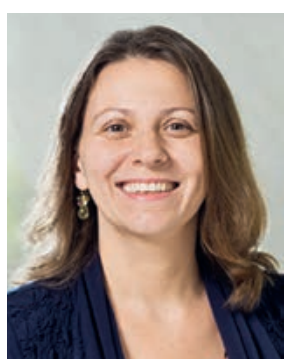

Magdalini Polymenidou is an Assistant Professor for Neurodegenerative Diseases at the Department of Quantitative Biomedicine of the University of Zurich. Her lab studies the molecular pathways triggering neurodegeneration in ALS and FTD. The team focuses on the formation and properties of the physiological and pathological states of TDP-43, FUS and the dipeptide repeat proteins, combining structural and biochemical analyses with cellular assays and animal models. Originally trained as a pharmacist in Aristotle University of Thessaloniki (Greece), she did her $\mathrm{PhD}$ on prion diseases in the laboratory of Adriano Aguzzi at the University Hospital of Zurich (Switzerland). As a postdoctoral fellow in the group of Don Cleveland at the University of California in San Diego (USA), she used genomewide approaches to understand the function of TDP-43 and FUS. She is an EMBO Young Investigator (2018) and an SNSF Assistant Professor (2013) and has been awarded the NIH Pathway to Independence Award (2011), the HFSP Career Development Award (2013) and the Georg-Friedrich Götz Prize (2015).

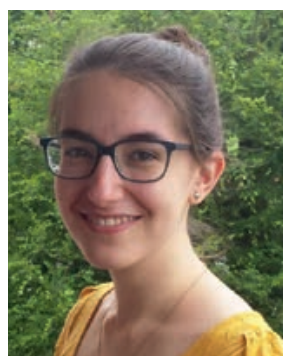

Manuela Pérez-Berlanga is a $\mathrm{PhD}$ candidate in Molecular Life Sciences at the Department of Quantitative Biomedicine at the University of Zurich working on the mechanisms of TDP-43 toxicity in neurodegeneration. She earned her $\mathrm{BSc}$ in Biochemistry at the Autonomous University of Madrid (Spain), which she combined with stays abroad, including the Biology Undergraduate Summer School (BUSS) at the University of Zurich in 2014. She then moved to Germany in 2015 to continue her studies with a Master in Biology at the
Ludwig-Maximilian University in Munich. She worked in the lab of Prof. Ulrich Hartl for her Master thesis, focusing on protein aggregation in ALS and FTD. She continued working as a research assistant in the Hartl lab for an additional year before the start of her $\mathrm{PhD}$ studies in the Polymenidou lab.

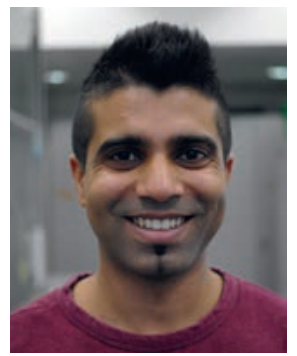

Tariq Afroz comes from Roorkee, a University town in the northern part of India. During his Masters, he studied Biotechnology at the Indian Institute of Technology in Mumbai (India). To pursue his interest in RNA and structural biology, he undertook his $\mathrm{PhD}$ at ETH Zürich, where he studied the role of sequence-specific protein-RNA interactions in translational gene regulation. Tariq joined the Polymenidou lab in November 2014 and focused on delineating the role of TDP43 and FUS/TLS in RNA processing, which when misregulated contributes to the ALS/FTD pathology. Since November 2017, Tariq joined AC Immune in Lausanne (Switzerland), which is a clinical-stage biopharmaceutical company focussed on treating neurodegenerative diseases associated with protein misfolding. At AC Immune, Tariq is working as pre-clinical research scientist to develop small molecule PET tracers (diagnostics) and therapeutics for neurodegenerative diseases. Outside the lab, he plays tennis and enjoys skiing and fondue in the winter.

\section{Introduction}

The identification of mutations in RNA binding proteins (RBPs) leading to an enhanced risk of developing neurological diseases has surged in the past decade. Such diseases encompass a diverse group, including amyotrophic lateral sclerosis (ALS) and frontotemporal dementia (FTD), ${ }^{[1]}$ spinocerebellar ataxia (SCA) ${ }^{[2]}$ and multisystem proteinopathies (MSP). ${ }^{[3]} \mathrm{A}$ common hallmark of 
these diverse diseases are alterations in RNA metabolism, which result from loss of function due to protein mislocalization and from gain of toxic functions by the accumulated pathological protein aggregates. ${ }^{[4]} \mathrm{A}$ key protein involved in virtually all cases of ALS and various forms of FTD is TAR (transactivation response) DNA binding protein of $43 \mathrm{kDa}$ (TDP-43). ${ }^{44 a, 5]} \mathrm{TDP}-43$ structurally belongs to a family of heterogeneous ribonucleoproteins (hnRNPs) and is primarily localized to the nucleus. ${ }^{[6]}$ Neurological disorders linked to TDP-43 pathology are classified as TDP-43 proteinopathies, ${ }^{[1,5]}$ and are characterized by nuclear clearance of TDP-43 and cytoplasmic TDP-43-positive inclusions that display characteristic pathological features such as ubiquitination, fragmentation and hyperphosphorylation. ${ }^{[1,5]}$ Most cases with TDP-43 pathology are sporadic, therefore lacking family history. ${ }^{[7]}$ Familial ALS cases due to mutations in TDP-43 are rare $^{[8]}$ and they also show the presence of cytoplasmic TDP-43-positive inclusions. Intriguingly, TDP-43-positive inclusions are also found in familial ALS linked to genetic mutations in proteins involved in degradation pathways such as UBQLN2,[9] SQSTM1,[10] VCP ${ }^{[11]}$ and OPTN. ${ }^{[12]}$ Why and how these mutations result in TDP-43 aggregation still remains elusive. Moreover, mutations in genes involved in RNA processing pathways, such as MATR3, [13] HNRNPA2B1, [14] HNRNPA1, [14] and C9ORF72 ${ }^{[15]}$ have been associated with TDP-43 proteinopathies. Therefore, different upstream alterations converge on TDP-43 aggregation in various neurodegenerative diseases, making TDP-43 an attractive target for both diagnosis and therapeutic interventions.

Here we review the structural determinants of TDP-43 function and dysfunction in health and disease. Based on various structural, biophysical, biochemical and in vivo data, we summarize our current understanding on the molecular mechanisms of TDP43 aggregation. A clear identification of the specific early events leading to TDP-43 misfolding or mislocalization is necessary for the development of preventive and disease-modifying therapeutics. At the same time, a clear distinction between the functional and pathological states is key for early diagnosis and for monitoring disease progression.

\section{Physiological Functions of TDP-43}

\section{Transcriptional Regulation}

TDP-43 encoded from the TARDBP gene located on human chromosome 1 was first identified as a protein factor that binds to the regulatory transactivation response element (TAR) of human immunodeficiency virus type 1 (HIV-1) to repress transcription. ${ }^{[16]}$ This binding gave TDP-43 its name (TAR DNA-binding protein of $43 \mathrm{kDa}$ ) but was later shown to be ineffective in altering the course of HIV-1 replication in human cells. [17] TDP-43 was also reported to act as a transcriptional repressor for the spermatidspecific gene $S P-10 .{ }^{[18]}$ More recently, the binding of TDP-43 to TG-rich sequences in the promoter region of $A C R V 1$, another spermatid-specific gene, was found to repress its transcription in testis. ${ }^{[19]}$ Moreover, TDP-43 is associated with transcriptionallyenriched euchromatin in rat neurons and in human brain, ${ }^{[20]}$ suggesting broad roles in transcription control.

\section{RNA Metabolism}

TDP-43 plays pleiotropic and important roles in RNA processing, including regulation of alternative splicing, RNA maturation, stability and trafficking. The first identified RNA target of TDP-43 is cystic fibrosis transmembrane conductance regulator (CFTR), whose alternative splicing is regulated by TDP-43 and other hnRNPs such as SR proteins. ${ }^{[21]}$ However, the major role of TDP-43 in RNA metabolism emerged in subsequent years with the genome-wide identification of several hundred RNA targets in human and mouse brain. ${ }^{[22]}$ Indeed, TDP-43 binds to numerous nascent RNA transcripts, both pre-mRNAs and non-coding RNAs, to control their fate and function. ${ }^{[23]}$
The sequence-specific RNA binding ${ }^{[21 \mathrm{a}, 24]}$ of TDP-43 via its two RNA recognition motifs (RRMs) ${ }^{[25]}$ mediates the interaction with over 6000 protein-coding RNA targets with high fidelity, which accounts for $30 \%$ of total murine transcriptome. ${ }^{[22]}$ The majority of TDP-43 binding sites (60\%) are located in long intronic regions of neuronal genes and this binding is required for sustaining their normal levels. ${ }^{[22 a]}$ The extensive intronic binding of TDP-43 facilitates the repression of cryptic exons, ${ }^{[26]}$ which are canonical exons that remain unused in physiological conditions. Cryptic exons often contain premature stop codons or polyadenylation sites that alter cellular RNA homeostasis and loss of TDP-43 function in disease was shown to interfere with this. ${ }^{[26]}$ An important and disease-relevant example of this regulation is the TDP-43 repression of a non-conserved cryptic polyadenylation site in the mRNA of the neuronal growth-associated factor stathmin-2, leading to the production of a truncated, non-functional mRNA that is devastating for neurons. ${ }^{[27]}$

The second most enriched TDP-43 binding sites (30\%) are those near canonical intron-exon junctions where it modulates the alternative splicing of the respective flanking exons. ${ }^{\text {[22a] }}$ In order to achieve this, TDP-43 acts in concert with other hnRNPs ${ }^{[21 b]}$ and can either enhance inclusion or exclusion of alternative exons depending on the location of the binding site. ${ }^{[22 a]}$ TDP-43 also binds to many non-coding RNAs such as nuclear-enriched autosomal transcript 1 (NEAT1) and metastasis-associated lung adenocarcinoma transcript 1 (MALAT1), whose expression is elevated in FTD-TDP patients. ${ }^{[22 b]}$ Lastly, TDP-43 has been shown to promote miRNA biogenesis and shown to be part of the Drosha and Dicer complexes ${ }^{[28]}$ and thereby regulates expression of several cancer associated miRNAs. ${ }^{[29]}$

\section{Translational Regulation and Response to Stress}

TDP-43 is primarily localized to the nucleus in a steady state, where it associates with its nucleic acid targets. ${ }^{[30]}$ However, under physiological conditions, TDP-43 actively shuttles between the nucleus and the cytoplasm, and a small percentage of the total cellular TDP-43 (up to $30 \%$ ) can be found in the latter compartment, ${ }^{[31]}$ where it associates with the 3'-UTR of its mature mRNA targets, ${ }^{[22 b]}$ thereby modulating their stability, localization and translation. ${ }^{[22 \mathrm{a}, 32]}$ Importantly, TDP-43 binds on the 3'-UTR of its own mRNA, to regulate its stability and translation, [22a,33] through a complex and finely controlled mechanism based on the combinatorial action of alternative splicing, polyadenylation site selection and translation. ${ }^{[32 b, 34]}$ For other mRNA targets, TDP-43 regulates either the mRNA stability, the transport, or the translation. ${ }^{[35]}$ Proteomic studies have shown that TDP-43 interacts with proteins involved in translation initiation and subsequent elongation factors. ${ }^{[36]}$ Moreover, TDP-43 may also control spatial translation by transporting mRNA to distal cellular sites such as axon terminals, thereby modulating local translation ${ }^{[37]}$ and regulating of axon growth ${ }^{[37 a]}$ and potentially other functions.

Finally, the ability of TDP-43 to phase separate into liquid droplets enables its recruitment into stress granules, which halt the translation of specific mRNAs during the cellular stress response. ${ }^{[38]}$ Both RNA binding and the low complexity region of TDP-43 are indispensable for its recruitment into stress granules. ${ }^{[38 a]}$ Regulation of stress granules dynamics via phase separation is an important area of interest due to the potential mechanistic similarity with the origin of pathologic aggregation ${ }^{[39]}$ (discussed later). Before discussing the molecular mechanisms of pathologic aggregation, we first summarize which regions of TDP-43 confer specific above-mentioned functional roles to the protein.

\section{Structural Determinants of TDP-43 Function}

The only human isoform of TDP-43 is the 414 amino acids (aa) long $43 \mathrm{kDa}$ protein, although a smaller alternative cDNA of 298 aa has been reported but not proved to be expressed. ${ }^{[40]}$ 
Similar to numerous other hnRNPs, ${ }^{[41]}$ TDP-43 has a modular multi-domain architecture comprising of an N-terminal domain (NTD), two RNA recognition motifs (RRMs) and a low complexity region (LCR) in the C-terminal part of the protein (Fig. 1). The N-terminal domain (NTD) and RRMs confer specific functional roles to the protein by mediating dynamic oligomerization $^{[42]}$ and selection of specific RNA targets, ${ }^{[25]}$ respectively. Additionally, TDP-43 harbours a bipartite nuclear localization signal (NLS) ${ }^{[30]}$ and predicted nuclear export signals (NES) ${ }^{[43]}$ allowing the protein to shuttle between the nucleus and cytosol.[30] The TDP-43 NLS is located in the linker region between the NTD and the RRMs and is comprised of a stretch of basic aa

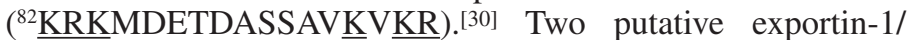
CRM1-dependent NES sequences have been predicted for TDP43, both localized within its RRM2: ${ }^{238} \underline{I A Q S L C G E D L I I ~}^{[31,43]}$ and ${ }^{222}$ IPKPFRAFAE. ${ }^{[44]}$ However, neither of the two NES sequences are functional, and a recent study conclusively showed that TDP43 leaves the nucleus by passive diffusion, ${ }^{[44]}$ similarly to other RNA-binding proteins linked to ALS like FUS. ${ }^{[45]}$

The complete three-dimensional structure of full length TDP43 remains to be resolved due to challenges in stability and solubility of protein samples required for biophysical and structural analysis. Nevertheless, high-resolution structures of individual domains complemented with cellular assays have resulted in models of TDP-43 that explain some of its functional properties and potential transitions to the pathological state. Here, we briefly summarize our existing knowledge gained from structural and biochemical studies using truncated TDP-43 domains.

\section{N-Terminal Domain Mediates Reversible TDP-43 Polymerization}

Shortly after the identification of TDP-43 as an aggregating protein in ALS and FTD, TDP-43 was shown to exist as dimers, which were suggested to act as seeds for pathologic inclusions in disease. ${ }^{[46]}$ However, it was not clear which structural elements were involved in TDP-43 dimerization until the first reports on the involvement of TDP-43's NTD in mediating oligomerization and increasing nucleic acid binding affinity. ${ }^{[47]}$ The first high-resolution NMR structural models of the monomeric TDP-43 NTD suggested that this domain structurally resembled ubiquitin ${ }^{[48]}$ and ubiquitin-like DIX ${ }^{49]}$ domains. The folded NTD (aa 1-80) was proposed to comprise of a stably folded $\beta$-sheet resulting from five anti-parallel $\beta$-strands that pack against an $\alpha$-helix. ${ }^{[49]}$ Additionally, one of the studies proposed that a nucleic aciddependent equilibrium between the folded and unfolded state of the NTD may influence aggregation of TDP-43. ${ }^{[48]}$ However, several more recent studies, including those from single molecule Förster resonance energy transfer (smFRET), demonstrate that this domain is stably folded near physiological solution conditions in vitro, ${ }^{[42,49,50]}$ refuting the notion of such folded-unfolded equilibrium.

Most recently, the high-resolution crystal structure revealed the molecular basis of TDP-43 polymerization via its NTD (Fig. 1). Together with cellular data, this structure showed the existence of functional oligomeric TDP-43 in physiological conditions. ${ }^{42]}$ TDP-43 NTD forms head-to-tail interactions that allow the protein to oligomerize in association with nucleic acids

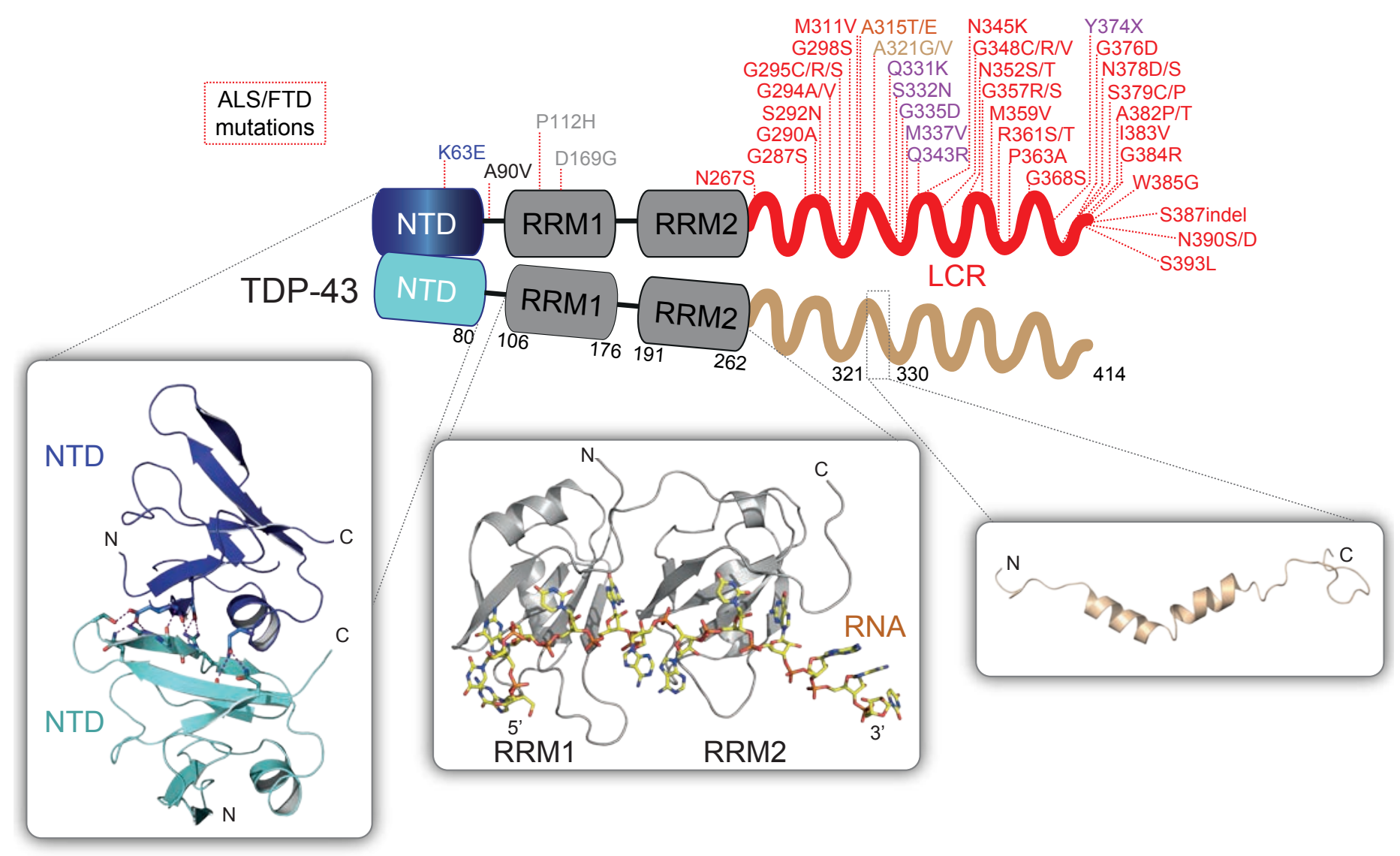

Fig. 1. Structure and domain organization of TDP-43. Schematic of modular domain organization of TDP-43 showing the N-terminal domain, RNA recognition motifs and low complexity region in blue, grey and red colors, respectively. TDP-43 forms oligomers mediated by interactions among the $\mathrm{N}$-terminal domains of adjacent TDP-43 molecules (shown in cyan). Known high-resolution structures of the corresponding regions of TDP-43 are shown below the schematic (Protein Data Bank 1D - 5MDI for NTD ${ }^{[42]}$, 4BS2 for RRMs ${ }^{[25]}$ and 2N3X for low complexity region ${ }^{[59 c]}$ ). Mutations identified in the familial cases of ALS and FTD cluster mainly in the low complexity region and are depicted on the corresponding TDP-43 schematic. ALS mutations are color-coded based on the protein domain that they are localized (blue for NTD, grey for RRM1 and red for LCR), except for those that fall into the LCR helical structure (braun) ${ }^{[59 c]}$ the reported steric zippers (purple) ${ }^{[61]}$ or LARKS (orange). ${ }^{[61]}$ The structures of the steric zippers and LARKS are not shown. 
in the nucleus, a step necessary for splicing regulation. ${ }^{[42,50 \mathrm{~b}]}$ Interestingly, a specific phosphorylation event within the NTD may function as a 'switch' regulating TDP-43 oligomerization in cells. ${ }^{[50 \mathrm{~b}]}$ In vitro, TDP-43 NTD binds to TG-rich sequences with a low affinity, a property that may stabilize the interaction of the full length protein to target RNAs. ${ }^{[42]}$ However, the structural basis of the NTD interaction with nucleic acids and the potential cooperativity with RRMs currently remains to be elucidated. Further high-resolution structural studies are necessary to reveal the quaternary structure of physiological TDP-43 oligomers in the nucleic-acid bound state. Likewise, the molecular basis of oligomerization-dependent splicing function of TDP-43 has not been determined yet.

\section{Nucleic Acid Binding by TDP-43 Tandem RRMs}

TDP-43 can bind to both DNA and RNA in a sequencespecific fashion, predominantly to TG/UG-rich sequences and also to other targets that may vary in sequence. ${ }^{[51]}$ The sequencespecificity is conferred by the tandem RRMs that bind 3-4 UG repeats per TDP-43 molecule, as revealed by the first crystal structures of isolated RRM1 ${ }^{[52]}$ and RRM2 ${ }^{[53]}$ in complex with TG-harboring DNA oligos. However, the distinct cooperativity in RNA recognition was shown from the solution structure of tandem RRMs in complex with UG-rich RNA (Fig. 1). ${ }^{[25]}$ Interestingly, the two RRMs are arranged in a manner that allows the formation of a continuous RNA binding surface required for binding longer sequences compared to a single RRM domain (Fig. 1). ${ }^{[25]}$ This mode of RNA binding is unique in comparison to other tandem $\mathrm{RRMs}^{[25,41]}$ with only similarity to the CPEB family of RNA binding proteins. ${ }^{[54]}$ However, the exact role of such RNA binding mode still remains unclear. One hypothesis is the potential organization of the NTD and the low complexity region (LCR) in a way that would favor homo- and hetero- molecular protein interactions. ${ }^{[25,42]}$ The crystal structure of RRM1 in complex with DNA suggests that RRM1 is crucial for nucleic acid recognition. ${ }^{[52]}$ Indeed, mutation of Phe147 and Phe149 that comprise the canonical RNP2 and RNP1 motif of RRM1, respectively, is sufficient to impair RNA binding of full-length TDP43. ${ }^{[52]}$ Interestingly, point mutations of residues involved in RNA binding (Phe147 and Phe149 in RRM1, Phe229 and Phe231 in RRM2) lead to the formation of nuclear TDP-43-positive inclusions, ${ }^{[30,55]}$ in accordance with recent work suggesting that RNA binding prevents aggregation of TDP-43 and other RNA-binding proteins. ${ }^{[56]}$ However, the nature of these inclusions does not resemble the pathological cytoplasmic aggregates seen in disease. ${ }^{[30]}$ Nevertheless, any post-translational modification (PTM) close to the RNA binding interface may well trigger the formation of such inclusions, which may result in pathological aggregation (discussed later). Indeed, acetylation of TDP-43 at Lys145 and Lys192 (Fig. 2) alters RNA interactions ${ }^{[55 b]}$ and results in nuclear inclusions that can be disaggregated by HSF-1 dependent chaperone. ${ }^{57]}$ Further PTMs close to RNA binding interface influencing RNA interactions are phosphorylations at Thr153 and Tyr155 by MEK in response to stress (Fig. 2). ${ }^{[58]}$ In fact, upon heat shock, this phosphorylated TDP-43 (pTDP-43) is specifically recruited to nucleoli and forms inclusions that are distinct from the pTDP-43 described in ALS/FTD patients. ${ }^{[58]}$

\section{Structure and Role of TDP-43 Low Complexity Region}

The C-terminal region of TDP-43 (aa 261-414) is a low complexity glycine-rich region that, isolated in solution, is primarily unstructured but contains a short $\alpha$-helix (aa 311-347) (Fig. 1). [59] TDP-43 LCRs have been reported to interact transiently via this $\alpha$-helix, ${ }^{[59 c]}$ which has been proposed to also interact with membranes, implying its potential in disrupting plasma membranes and other organelles like $A \beta .{ }^{[59 b]}$ Adjacent to this $\alpha$-helix is a $Q / N$ rich sequence that has been suggested to form amyloidogenic cross $\beta$-sheet structures showing a unique $\mathrm{X}$-ray fiber diffraction pattern distinct from other amyloids. ${ }^{[60]}$ More recently, multiple short segments of the TDP-43 LCR were shown to form either steric zippers or reversible amyloid-like structures termed LARKS (low-complexity aromatic-rich kinked segments) in vitro, ${ }^{[61]} \mathrm{sug}$ gesting that this region may form complex and heterogeneous assemblies in cells.

TDP-43 LCR has multifaceted functions and has been proposed to mediate protein-protein and potentially stabilize protein-RNA interactions and is essential for TDP-43 splicing activity. ${ }^{[21 b, 24]}$ Similar to other hnRNPs like FUS, ${ }^{[62]}$ the ${ }^{293}$ RGG motif of TDP-43 LCR may modulate its affinity for target RNAs. ${ }^{[63]}$ Indeed, arginine methylation in this motif may alter TDP-43 RNA interactions and enhance aggregation (Fig. 2). ${ }^{[64]}$ Moreover, TDP43 interacts with another splicing factor hnRNAP A1 via the region of LCR localized (321-366) in the $\alpha$-helix, ${ }^{[21 b]}$ where three reported steric zipper segments are also localized.[61]

Importantly, the LCR of TDP-43 can phase separate into liquid droplets that potentially allows an increase in its local concentration at specific locations inside the cells. ${ }^{[38 b, 39 a, 59 c, 65]}$ Phase separation has been suggested as an initial event leading to the formation of membrane-less organelles, ${ }^{[39 a, 65 a, 66]}$ such as stress granules, via the transient interaction of LCRs of multiple RNAbinding proteins. Phase separation also makes the protein vulnerable to aggregation and transition to pathology, ${ }_{,}^{[39 a]}$ although this transition was recently reported to be independent from stress granule formation. ${ }^{[65 \mathrm{~b}, \mathrm{c}]}$ Most of the genetic mutations related to TDP-43 proteinopathies cluster in the LCR of TDP-43 and increase its aggregation propensity[67] (Fig. 1). Proposed structural transitions resulting from specific disease-causing modifications or PTMs are discussed later in context of molecular mechanisms of TDP-43 aggregation.

Fig. 2. Post-translational modifications of TDP-43. Various experimentally validated posttranslational modifications are depicted on the schematic structure of TDP-43, including acetylation on specific lysines (shown in green), sumoylation (magenta), phosphorylation (red), methylation (blue) and cleavage by caspase-3 (depicted by red scissors).

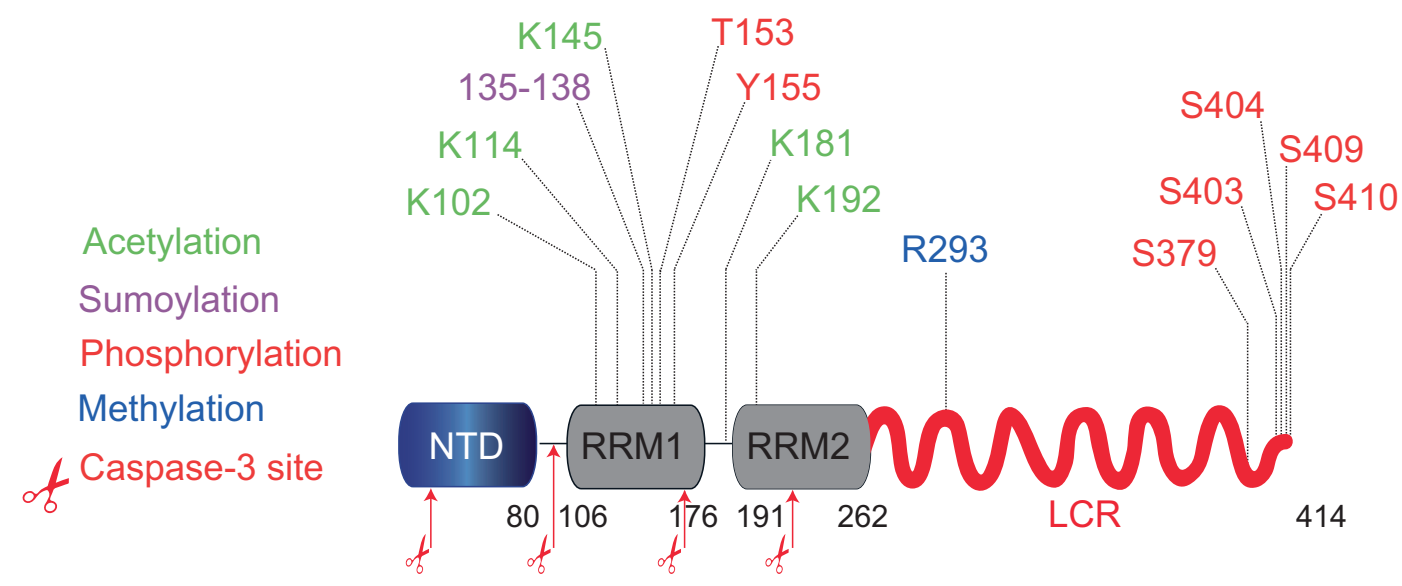




\section{TDP-43 Proteinopathies}

TDP-43 was first identified in 2006 as the major aggregated protein in the ubiquitinated and phosphorylated cytoplasmic inclusions found in the neurons of patients with ALS and FTD. ${ }^{[5]}$ TDP-43-positive inclusions were subsequently found in the majority of ALS patients (97\%), in both sporadic and familial cases (with the exceptions of SODI-ALS and FUS-ALS). ${ }^{[4 a]}$ However, TDP-43 pathology is not restricted to ALS and FTD, but is also found in other neurodegenerative diseases, such $\sim 25 \%$ of patients with Alzheimer's disease, $\sim 70 \%$ of patients with hippocampal sclerosis and in a small subset of cases with Lewy body disorders, Pick's disease, corticobasal degeneration, agyrophilic grain disease and Huntington's disease. ${ }^{[68]}$ Interestingly, TDP-43-positive inclusions with different shapes are also a feature in all tested cases of the well-known ALS and Parkinsonism-dementia complex (PDC) of unknown etiology in the Chamorro population of Guam. ${ }^{[69]}$ Considering the above-mentioned studies, it is conceivable that a combination of a particular proteinopathy in concert with TDP-43 pathology may result in a very specific clinical presentation. Neurodegenerative diseases linked to the primary deposition of both full-length and fragmented TDP-43 showing specific PTMs and detergent insolubility are collectively termed 'TDP-43 proteinopathies'.[5]

\section{TDP-43 Loss of Function}

The relative contributions of the loss of function and gain of toxicity from TDP-43 to disease progression are still not fully elucidated. While TDP-43 cytoplasmic inclusions are a hallmark of TDP-43 proteinopathies, the aggregation of this protein and the regions it affects can vary across patients. ${ }^{[7]}$ For example, a percentage of affected cells in FTLD and sporadic ALS patients do not display aggregates but rather show nuclear clearance with only diffuse cytoplasmic staining. ${ }^{[70]}$ Such TDP-43 mislocalization is thought to precede aggregation of the protein, ${ }^{[70 a]}$ and clearly demonstrates an early loss of TDP-43 function mechanism operating in those affected cells. Being involved in diverse cellular processes, loss of TDP-43 is certainly detrimental to the cell, as shown by early lethality of TDP-43 homozygous knockout mice. ${ }^{[71]}$

Depletion of TDP-43 in cellular and animal models results in an overall alteration of RNA metabolism in ALS/FTD. [4a,22,27] TDP-43 targets some of the neuron-enriched long genes expressed in the human brain. ${ }^{[22 \mathrm{a}]}$ Misregulated expression of these genes such as those encoding for neurexin 3 (NRXN3), parkin $(P R K N)$ or progranulin $(G R N)$ may be specifically detrimental to neurons than other cell types in the brain. ${ }^{[22 a]}$ Specifically, widespread splicing alterations of direct and indirect TDP-43 targets have been reported in animal models and humans. ${ }^{[22]}$ Most interestingly, mouse models that showed abnormal splicing patterns of TDP-43 targets resulting from a partial loss of TDP-43 or from the expression of ALS-linked mutated TDP-43 developed ALS-like phenotypes lacking cytoplasmic inclusions. ${ }^{[72]}$

It is worth to remark that, among the targets of TDP-43, one can find the mRNAs encoding for other proteins that aggregate in different neurodegenerative disorders, such as FUS, amyloid precursor protein (APP), huntingtin, $\alpha$-synuclein, progranulin and tau.[22a] TDP-43 controls either the levels or the splicing of these mRNAs. ${ }^{[22 a]}$ In fact, TDP-43 pathology has been observed in brains of patients suffering from Alzheimer's disease and the aforementioned Guam-PDC, which present with tau neurofibrillary tangles as a characteristic feature. ${ }^{[68 g, 69 a, b]}$ It has recently been reported that TDP-43 controls the alternative splicing of tau and, when mutated, promotes the misregulation of the ratio of the two tau isoforms, an alteration seen in several tauopathies. ${ }^{[73]}$ Furthermore, TDP-43 has also been shown to potentiate toxicity in dopaminergic neurons of transgenic mice, suggesting a synergistic interplay between TDP-43 and $\alpha$-synuclein. ${ }^{[74]}$ Therefore, alterations in nuclear TDP-43 levels increases the risk of misregulation of other proteins levels and isoforms in diseases.

Intriguingly, even though TDP-43 loss of function contributes to disease progression, the majority of cellular and animal models of TDP-43 have failed to fully recapitulate the ALS/FTD-TDP pathology. ${ }^{[72,75]}$ Therefore, even though loss of TDP-43 function is a consistent feature in TDP-43 proteinopathies and suggests a direct involvement in the neuron phenotype, it alone cannot fully explain the disease progression in animal models of motor neuron disease. ${ }^{[4 a]}$

\section{Pathologic Assemblies of TDP-43}

TDP-43 aggregates are the main hallmark of TDP-43 proteinopathies, yet the role in disease remains unclear. From protective structures that sequester potentially toxic misfolded proteins to composing the main toxic species, TDP-43 aggregates have even been suggested to represent an irrelevant structure that correlates with the true toxic phenomenon. ${ }^{[76]}$ All three possibilities are compatible with their presence in disease-affected neurons. TDP-43 aggregates display specific characteristics such as predominant cytoplasmic localization, proteolytic fragmentation and PTMs such as ubiquitination and phosphorylation (Fig. 2). ${ }^{[5]}$ Although not as abundant, nuclear pTDP-43 inclusions have also been reported in patients with different types of familial FTD. ${ }^{[5,77]}$

Currently, the molecular architecture of cytoplasmic pathological TDP-43 assemblies is enigmatic and remains to be determined at higher resolution. Most of the pathological TDP-43 inclusions present with non-amyloidogenic features and concomitantly do not show reactivity to amyloid specific dyes such as Congo red and thioflavin $\mathrm{T}$ and $\mathrm{S}$, displaying instead a granular or amorphous non-filamentous morphology. ${ }^{[78]}$ In line with these findings, bacterially expressed TDP-43 was reported to form amorphous aggregates in transmission electron or atomic force microscopy studies. ${ }^{[79]}$ However, other studies have reported filamentous TDP-43 structures in some patient brains ${ }^{[20 b, 80]}$ and in a subset of ALS cases thin TDP-43 skein-like filaments in spinal motor neurons are positive to thioflavin $\mathrm{S} .{ }^{[81]}$ Furthermore, recombinant full-length TDP-43 has been reported to form amyloidlike spherical oligomers as observed by transmission electron and atomic force microscopy, and said structures could be detected by an oligomer specific antibody in the FTLD brain tissues. ${ }^{82]}$ Moreover, recent studies reported polymorphic amyloid or labile amyloid-like structures formed by short synthetic TDP-43 fragments residing within its RRM2,[83] and LCR. ${ }^{[61]}$

These contradictory results may potentially originate from differences in protocols used to purify recombinant proteins, which may lead to heterogeneous preparations comprising a mixture of soluble oligomers, misfolded protein precipitates, disordered aggregates or eventually specific ordered aggregates. Currently, it is difficult to determine which of these species bears resemblance (if any) to the pathological protein aggregates seen in patients. Isolation of aggregated pathological TDP-43 from brain tissue has been difficult due to its co-purification with physiological TDP-43 and other RNA-binding proteins. Recently, a new method for enrichment of pathological TDP-43 devoid from other physiological interactors opened the door to detailed biochemical analysis of different TDP-43 assemblies isolated from patient samples. ${ }^{[84]}$ Such a method may allow the high-resolution structural determination of patient-derived pathological TDP-43 assemblies. Moreover, it is likely that TDP-43 forms heterogeneous pathologic assemblies within patient tissues, a notion strongly supported by the different morphology ${ }^{[85]}$ and biochemical properties ${ }^{[84]}$ of pathological TDP-43 assemblies from different disease subtypes, as well as the ability of TDP-43 segments to form polymorphic structures in vitro. ${ }^{[61,83]}$ Pure isolation of pathological TDP-43 from autopsy brain from patients with distinct FTLD subtypes allowed the identification of large TDP-43 assemblies with distinct 
features, including size, density, shape, proteolytic resistance and ubiquitination. ${ }^{[84]}$ Importantly, these isolated TDP-43 assemblies also showed distinct neurotoxicity and seeding ability, which correlated with the disease duration of the patients they originated from, suggesting that the molecular pathologic TDP-43 signature may determine specific clinical characteristics. ${ }^{[84]}$

Various proteolytic fragments have been reported to be present in the pathologic inclusions in addition to the full-length TDP43. ${ }^{[5,86]}$ The first fragments identified in FTLD patients were TDP43 C-terminal ends of $\sim 25 \mathrm{kDa}$ and $\sim 35 \mathrm{kDa}$ in size, which were termed CTF25 and CTF35, respectively. ${ }^{[5,87]}$ These fragments are thought to occur by cleavage of TDP-43 by caspase- 3 and $-7[87,88]$ (Fig. 2). However, the advancement of proteomic methods has allowed the identification and characterization of other C-terminal TDP-43 fragments produced by other proteases in ALS and FTLD. ${ }^{[86,89]}$ Interestingly, several mutations in TDP-43 known to cause ALS have been linked to an alteration in the proteolytic pattern of TDP-43 in vitro, in cellular models and in patients. ${ }^{[8,90]}$ Proteolysis of TDP-43 results in truncated fragments lacking the NLS and at least one RNA binding domain, which results in the loss of function and localization of the fragmented protein into the cytoplasm. ${ }^{\text {88a] }}$ Moreover, these mislocalized fragments containing the LCR have a higher propensity to form aggregates, ${ }^{[88 a]}$ which can drive the sequestration of full-length TDP-43, leading to the decrease of its functional pool. ${ }^{[91]}$

Pathologic TDP-43 aggregates further adopt other PTMs such as phosphorylation, ${ }^{[5]}$ ubiquitination, ${ }^{[5]}$ sumoylation ${ }^{[92]}$ and acetylation. ${ }^{[55 b]}$ TDP-43 phosphorylation at serines 379, 403, 404, 409 and 410 is the best studied disease-associated PTM of TDP-43 and is exclusively labeling pathological species (Fig. 2). ${ }^{[5,77 b]}$ Casein kinase 1 (CK1) has been implicated in TDP-43 phosphorylation in patients ${ }^{[93]}$ and CK1 levels are elevated in neurons with pTDP-43, potentially via a regulatory loop in which TDP-43 binds and regulates CSNK1 mRNA levels and CK1 in turn directly phosphorylates TDP-43. ${ }^{[93 \mathrm{~b}]}$ While TDP-43 phosphorylation is a useful pathological mark, its role in the disease process remains unclear. Nevertheless, several lines of evidence suggest that phosphorylation modulates TDP-43 aggregation and toxicity. CK1 was shown to directly phosphorylate TDP-43 in cellular models ${ }^{[77 b, 94]}$ and to enhance toxicity of ALS-linked TDP-43 mutants in a Drosophila model. ${ }^{[95]}$ In line with this, pTDP-43 has been shown to persist longer and to exhibit greater insolubility than unmodified TDP43 in cells. ${ }^{[96]}$ Blocking phosphorylation via mutating serines 409 and 410 to alanines alleviate aggregation in cells ${ }^{[97]}$ and the same mutations were shown to mitigate neurotoxicity in C. elegans, ${ }^{[98]}$ collectively indicating that phosphorylation is a critical step in the maturation and toxicity of pathological TDP-43 assemblies.

The mechanism of pathological TDP-43 toxicity remains unknown, but it has been hypothesized that sequestration of other proteins and/or cellular RNA may contribute to toxicity. This was supported by the idea that TDP-43 aggregates evolve gradually from physiological stress granules, containing multiple RNA binding proteins and RNAs, some of which might remain trapped in the pathological assemblies. Supporting this view, in cellular models TDP-43 aggregates have been shown to sequester other proteins, especially RBPs and stress granule markers, such as TIA-1, TIAR and PABP. ${ }^{[64,99]}$ Yet, the evidence from human brain is less conclusive. The majority of hnRNPs were not found to co-localize with TDP-43-positive inclusions, ${ }^{[100]}$ although some reports suggest coaggregation of specific candidate RNA binding proteins, including TIA-1 and eIF3, ${ }^{[99}$ a] (Poly-A binding protein-1) PABP1 in FTD patients with $C 9$ orf72 mutations ${ }^{[101]}$ and hnRNP E2 in semantic dementia but not in other TDP-43 proteinopathies. ${ }^{[102]}$ Our more recent unbiased approach using mass spectrometry on biochemically isolated TDP-43 aggregates did not reveal any stress granule proteins. ${ }^{[84]}$ In line with this, two latest studies showed that, while TDP43 aggregates in cells indeed evolve from phase separated cytoplas- mic compartments, these are independent from stress granules and are devoid of other proteins or RNA, ${ }^{[65 b, c]}$ while a contemporaneous study found that stress granule assembly can initiate ALS/FTD-like pathological TDP-43 inclusions in cells. ${ }^{[103]}$ While this important point remains to be clarified, a likely scenario is that more than one pathway results in the formation in pathological assemblies and phase separation plays a key role in the process.

\section{TDP-43 Pathogenic Mechanisms - Transition from Physiological to Pathological State}

Early events leading to TDP-43 pathology, including nuclear clearance and cytoplasmic aggregation, remain unclear both in familial and sporadic cases. Since the majority of pathological aggregates identified in disease-affected neurons are localized in the cytoplasm, the transition from the physiological to the pathological cytoplasmic aggregated state is potentially preceded by cytoplasmic mislocalization (Fig. 3).[70a] Here, we summarize our current understanding of the molecular basis of transitions from physiological to pathological state initially characterized by a misfolding event. Most of the mutations in familial cases of TDP43 proteinopathies are localized in the LCR (Fig. 1) and only a few mutations (A90V, P112H and D169G in Fig. 1) ${ }^{[90 c, 104]}$ in the $\mathrm{N}$-terminal half (aa 1-265), suggesting a conserved role of this region for protein function. The mutations have been proposed to induce misfolding and enhance aggregation propensity of the protein. ${ }^{[67]}$ However, since most of TDP-43 proteinopathies are sporadic in nature, in the following section we focus on de novo mechanisms of TDP-43 aggregation.

\section{TDP-43 NTD \& LCR - Antagonist and Agonist of Pathological Aggregation?}

The role of TDP-43 NTD in influencing pathological aggregation remains controversial. Some studies suggest that since the NTD brings two TDP-43 molecules into proximity, this region must promote inclusion formation. ${ }^{[47 b, 105]}$ However, recent biochemical and cellular data points to a preventive role of NTDmediated dynamic oligomerization in irreversible protein aggregation. ${ }^{[42]}$ Indeed, NTD-mediated interactions should potentially bring various TDP-43 molecules together to enhance aggregation. However, due to lack of high-resolution structural data on full-length protein, it is difficult to predict the positions of the LCRs relative to the other domains in TDP-43 protein-RNA oligomers. Structural analysis of full-length protein in complex with nucleic acids is indispensable to determine the dynamics and spatial organization of TDP-43 LCR's. In vitro, recombinant TDP-43 LCR in isolation shows a minor population displaying transient inter-molecular interactions in the $\alpha$-helical region of TDP-43. [59c] However, it is not clear if a similar interaction occurs in vivo in the context of full-length protein in complex with nucleic acids. The cellular data using GFP complementation show that the NTD-mediated interactions spatially separate the LCRs of TDP-43 impeding their interaction. ${ }^{[42,106]}$ Therefore, the dynamic NTD-mediated intermolecular interactions in complex with nucleic acids potentially prevent its aggregation. ${ }^{[42]}$ This observation is further supported by subsequent independent studies, which show that either deletion of NTD ${ }^{[73]}$ or dimerization-impaired ${ }^{[107]}$ TDP-43 increases inclusion formation in cells suggesting its protective role in preventing aggregation in healthy state. A different approach reported that oligomerization disruption by a specific phosphorylation event within the NTD reduces TDP-43 liquidliquid phase separation in vitro and in cells. ${ }^{[50 b]}$ Therefore, any factor altering TDP-43 oligomerization and/or nucleic acid binding would destabilize native TDP-43 oligomers (Fig. 3), thereby disturbing the equilibrium between the nuclear oligomeric and monomeric TDP-43, which may result in cytoplasmic mislocalization due to passive diffusion. ${ }^{[35,45]}$ Below we summarize various mechanisms that might potentially alter this native equilibrium. 


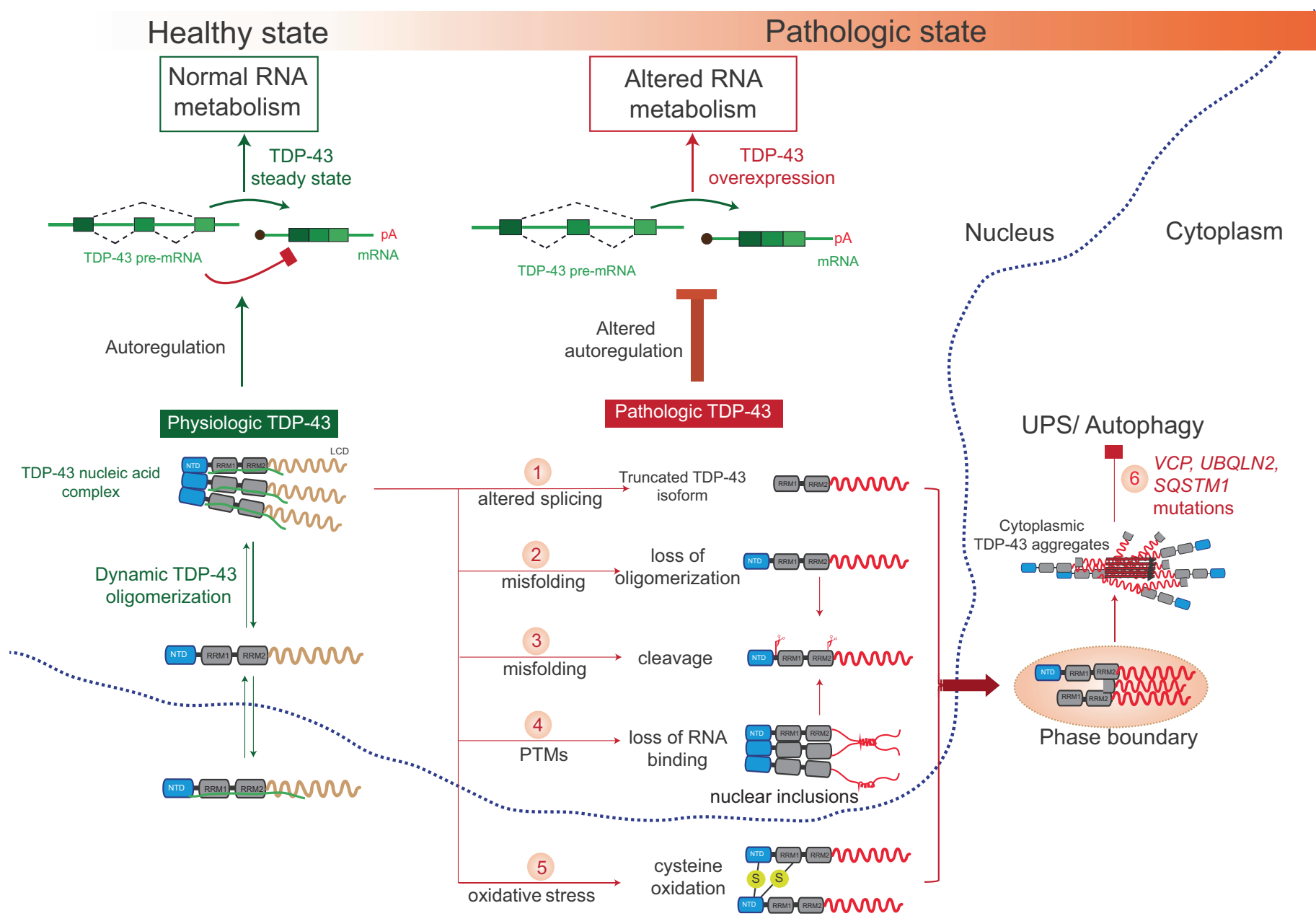

Fig. 3. Molecular mechanisms of TDP-43 aggregation. In the healthy state, the majority of TDP-43 is in the nucleus where it forms functional and dynamic oligomers. This functional TDP-43 maintains its own steady state levels via an autoregulatory mechanism and in turn regulates the normal RNA homeostasis of the cell. However, various events may initiate the pathologic cascade that may independently or in concert result in pathologic aggregation of TDP-43. Altered RNA splicing (1), TDP-43 misfolding due to environmental factors $(2,3)$ or specific PTMs (4) and stress (5) may lead to pathologic aggregation of TDP-43. Some of these events $(1,2,3)$ may induce cytoplasmic mislocalization. As TDP-43 translocates to the cytosol, there may be specific regions with high TDP- 43 concentration that can lead to phase separation via its low complexity region. Such droplets may be the precursors of the mature pathological aggregates seen in disease. Moreover, mutations in protein degradation pathways (6) enhance the accumulation of these pathologic aggregates.

\section{Altered Equilibrium between Physiological States}

Splicing alterations have been reported to increase the expression levels of a truncated isoform of TDP-43 in ALS patients, ${ }^{[108]}$ resulting from usage of the alternative start codon $\mathrm{ATG}^{\mathrm{Met} 85}$, which leads to the deletion of $91 \mathrm{bp}$ in exon 2. This isoform decodes a protein lacking the extreme NTD that is important for mediating the nuclear dynamic protein oligomerization, ${ }^{[42,106]}$ and shows enhanced cytoplasmic localization due to lack of one region of the bipartite NLS. ${ }^{[108]}$ This truncated protein has increased insolubility compared to full-length TDP-43 and was shown to form inclusions in ALS patients. ${ }^{[108]}$ This mechanism highlights the importance of either expression of truncated protein or proteolytic cleavage resulting in similar fragments mislocalized to the cytoplasm as an early event in the formation of pathologic aggregates (Fig. 3). TDP-43 has multiple predicted caspase-3 and calpain cleavage sites. ${ }^{[00 a]}$ Specific cell signaling triggered by brain trauma events may result in the activation of these proteases resulting in TDP-43 cleavage. ${ }^{[109]}$ Such signaling events may differ in each disease subtype that may result in a characteristic cleavage pattern that is often associated with them. Caspase- 3 activity has been linked to the levels of progranulin, ${ }^{[87]}$ whose mutation itself also increases the risk of developing FTD. ${ }^{[110]}$ As indicated before, genetic mutations in TDP-43 also alter its proteolytic susceptibility. D169G mutation in RRM2 increases the thermal stability of the mutant protein and enhances cleavage by caspase- 3 resulting in the production of CTF25. ${ }^{[90 \mathrm{~b}]}$ Cleavage of TDP-43 within RRM2 removes the NTD and therefore disrupts functional and dynamic interactions. ${ }^{[42]}$ It was reported that the two $\beta$-strands within RRM2 - $\beta 3$ and $\beta 5$ are prone to fibril formation similar to amyloids. ${ }^{[111]}$ The proteolytic cleavage within RRM2 domain would expose this region for fibril formation. ${ }^{[111]}$ On the other hand, the A90V mutation is present adjacent to the NTD in the linker region harboring the NLS and caspase- 3 cleavage site. Such a mutation may potentially either alter the protein localization or its ability to be cleaved by caspase-3. ${ }^{[90 a]}$ Mass spectrometry of pathological inclusions in ALS have revealed additional cleaved fragments of TDP-43 corresponding to different unreported cleavage sites, ${ }^{[86]}$ strengthening the hypothesis of TDP-43 cleavage in mislocalization and initiation of aggregate formation in the cytoplasm.

\section{Environmental Stressors}

The amino acid sequence of TDP-43 contains six cysteine residues, two of which are located in the NTD (Cys39 and Cys50), while the other four are located in the RRMs (Cys173, Cys175, Cys198 and Cys244). Based on the structures of isolated TDP-43 domains, no inter- or intra-molecular disulphide bonds have been identified in the native state. ${ }^{[25,42]}$ In this folded state, Cys39 and Cys50 are surface exposed but do not engage in disulphide bond formation in vitro. ${ }^{[42]}$ Moreover, from the structure of TDP-43 RRMs in complex with RNA, it is known that the four cysteines 
in the RRMs are buried in the core of the $\mathrm{RRMs}^{[25]}$ and would potentially not engage in disulphide bond formation unless the protein is misfolded. Interestingly, no cysteine mutations have been reported so far in ALS/FTD. However, upon oxidative stress, full length TDP-43 is mislocalized from the nucleus to the cytosol and forms large aggregates in addition to small oligomers (Fig. 3). ${ }^{[112]}$ Oxidative stress in the cytosol can induce the formation of inter-molecular disulphide bonds. ${ }^{[12 a]}$ Studies on the aggregation process have shown that oxidation of cysteines located in the two RRMs decreases protein solubility, leading to the formation of intra and inter-molecular disulphide linkage, ${ }^{[112 a, 113]}$ and that cysteine residues in RRM1 direct the conformation of TDP-43.[114] Similarly, induced intermolecular disulphide bonds in RRM2 show increased aggregation behaviour. ${ }^{[115]}$ Such disulphidelinked TDP-43 multimers have also been detected in a transgenic mouse model of TDP-43 harbouring the A315T mutation. ${ }^{[116]}$ Intriguingly, interaction of zinc ions with the two RRMs of TDP43 occurs with micromolar affinity and triggers structural modifications that decrease its thermostability, ${ }^{[117]}$ potentially leading to intracellular aggregation of TDP-43.[118]

\section{Other Genetic F actors}

Apart from TDP-43, mutations in many other genes have been identified to cause TDP-43 proteinopathies. These mutations either belong to genes involved in the RNA processing pathway or in protein degradation pathways. ${ }^{[4 a, 67]}$ In the former category, mutations in genes such as MATR3,[13] hnRNPA1,[14] TIA1 [119] and $C 9 O R F 72^{[15,120]}$ lead to diverse alterations in RNA processing events. Moreover, a hexanucleotide expansion mutation in C9ORF72 also leads to expression of dipeptide repeat proteins (DPRs), which have been shown to interact with TDP-43 via the LCR $^{[121]}$ and to impair TDP-43 import into the nucleus. ${ }^{[122] ~ I n ~}$ the latter category, included are genes like $V C P, U B Q L N 2$ and SQSTM1 involved in the UPS or in autophagy, both of which help maintain protein homeostasis. ${ }^{[67]}$ Indeed, these pathways are in charge of eliminating misfolded proteins or protein aggregates, respectively. What determines the occurrence of TDP-43 pathology in multiple neurodegenerative diseases and why other hnRNPs with significant structural and functional similarity to TDP-43 are less frequently transformed to pathogenic entities remains unknown. Nevertheless, this predominance of TDP-43 pathology is intriguing and makes it one of the most suited therapeutic and diagnostic targets for various neurodegenerative diseases.

\section{Challenges in Therapeutics \& Diagnostics}

Currently, a major challenge in TDP-43 proteinopathies is the distinction between functional and pathological states of TDP43. This is complicated by the fact that pathological states may be very diverse depending on the specific disease subtype. ${ }^{[7,84,85]}$ It remains unclear which of the pathological TDP-43 species are toxic and which may represent the end result of a pathogenic pathway. Indeed, similar to $\alpha$-synuclein, ${ }^{[123]}$ small oligomers may represent the toxic species that are primarily responsible for disease progression and spread of pathology. This highlights the need for high-resolution structural determination of all physiological and pathological states of TDP-43 and mapping of structure-function-toxicity relationships. This is essential for the development of diagnostic tools to enable both early diagnosis, but also the monitoring of disease progression that will permit evaluation of disease-modifying therapeutics. Structural transitions triggering misfolding, mislocalization and aggregation of TDP-43 must be characterized at the molecular level for a rational design of diagnostic and therapeutic agents. Moreover, pathological TDP-43 species were shown to seed aggregation and trigger toxicity in cellular $^{[65 b, 84,124]}$ and animal ${ }^{[125]}$ models. The molecular and cellular determinants of this important mechanism that likely underlies spreading and propagation of TDP-43 pathology within a patient's nervous system ${ }^{[126]}$ urgently needs to be elucidated, as it may lead to the identification of new molecular targets for therapeutic interventions to treat these devastating diseases.

\section{Acknowledgements}

This work was supported by research grants from the Swiss National Science Foundation (PP00P3_144862), Sinergia (CRSII5_170976) and the NCCR RNA \& Disease. We thank the members from the lab of Prof. Polymenidou for critical reading, suggestions and discussions.

\section{Conflict of Interest}

The authors have no conflict of interest to declare.

Received: April 21, 2019

[1] A. S. Chen-Plotkin, V. M. Lee, J. Q. Trojanowski, Nat. Rev. Neurol. 2010, 6 , 211, DOI: 10.1038/nrneurol.2010.18.

[2] S. Banfi, A. Servadio, M. Y. Chung, T. J. Kwiatkowski, Jr., A. E. McCall, L. A. Duvick, Y. Shen, E. J. Roth, H. T. Orr, H. Y. Zoghbi, Nat. Genet. 1994, 7, 513, DOI: 10.1038/ng0894-513.

[3] F. Geser, M. Martinez-Lage, J. Robinson, K. Uryu, M. Neumann, N. J. Brandmeir, S. X. Xie, L. K. Kwong, L. Elman, L. McCluskey, C. M. Clark, J. Malunda, B. L. Miller, E. A. Zimmerman, J. Qian, V. Van Deerlin, M. Grossman, V. M. Lee, J. Q. Trojanowski, Arch. Neurol. 2009, 66, 180, DOI 10.1001/archneurol.2008.558.

[4] a) S. C. Ling, M. Polymenidou, D. W. Cleveland, Neuron 2013, 79, 416 , DOI: 10.1016/j.neuron.2013.07.033; b) A. F. Harrison, J. Shorter, Biochem. J. 2017, 474, 1417, DOI: 10.1042/BCJ20160499.

[5] M. Neumann, D. M. Sampathu, L. K. Kwong, A. C. Truax, M. C. Micsenyi, T T. Chou, J. Bruce, T. Schuck, M. Grossman, C. M. Clark, L. F. McCluskey, B. L. Miller, E. Masliah, I. R. Mackenzie, H. Feldman, W. Feiden, H. A Kretzschmar, J. Q. Trojanowski, V. M. Lee, Science 2006, 314, 130, DOI: 10.1126/science. 1134108 .

[6] E. Buratti, F. E. Baralle, Trends Biochem. Sci. 2012, 37, 237, DOI: 10.1016/j. tibs.2012.03.003.

[7] M. Neumann, Int. J. Mol. Sci. 2009, 10, 232, DOI: 10.3390/ijms10010232.

[8] J. Sreedharan, I. P. Blair, V. B. Tripathi, X. Hu, C. Vance, B. Rogelj, S. Ackerley, J. C. Durnall, K. L. Williams, E. Buratti, F. Baralle, J. de Belleroche, J. D. Mitchell, P. N. Leigh, A. Al-Chalabi, C. C. Miller, G. Nicholson, C. E. Shaw, Science 2008, 319, 1668, DOI: 10.1126/science. 1154584 .

[9] H. X. Deng, W. Chen, S. T. Hong, K. M. Boycott, G. H. Gorrie, N. Siddique, Y. Yang, F. Fecto, Y. Shi, H. Zhai, H. Jiang, M. Hirano, E. Rampersaud, G. H. Jansen, S. Donkervoort, E. H. Bigio, B. R. Brooks, K. Ajroud, R. L. Sufit, J. L. Haines, E. Mugnaini, M. A. Pericak-Vance, T. Siddique, Nature 2011, 477, 211, DOI: 10.1038/nature10353.

[10] E. Rubino, I. Rainero, A. Chio, E. Rogaeva, D. Galimberti, P. Fenoglio, Y. Grinberg, G. Isaia, A. Calvo, S. Gentile, A. C. Bruni, P. H. St GeorgeHyslop, E. Scarpini, S. Gallone, L. Pinessi, T. S. Group, Neurology 2012, 79, 1556, DOI: 10.1212/WNL.0b013e31826e25df.

[11] G. D. Watts, J. Wymer, M. J. Kovach, S. G. Mehta, S. Mumm, D. Darvish, A. Pestronk, M. P. Whyte, V. E. Kimonis, Nat. Genet. 2004, 36, 377, DOI: $10.1038 / n g 1332$.

[12] H. Maruyama, H. Morino, H. Ito, Y. Izumi, H. Kato, Y. Watanabe, Y. Kinoshita, M. Kamada, H. Nodera, H. Suzuki, O. Komure, S. Matsuura, K. Kobatake, N. Morimoto, K. Abe, N. Suzuki, M. Aoki, A. Kawata, T. Hirai, T. Kato, K. Ogasawara, A. Hirano, T. Takumi, H. Kusaka, K. Hagiwara, R. Kaji, H. Kawakami, Nature 2010, 465, 223, DOI: 10.1038/nature08971.

[13] J. O. Johnson, E. P. Pioro, A. Boehringer, R. Chia, H. Feit, A. E. Renton, H. A. Pliner, Y. Abramzon, G. Marangi, B. J. Winborn, J. R. Gibbs, M. A. Nalls, S. Morgan, M. Shoai, J. Hardy, A. Pittman, R. W. Orrell, A Malaspina, K. C. Sidle, P. Fratta, M. B. Harms, R. H. Baloh, A. Pestronk, C. C. Weihl, E. Rogaeva, L. Zinman, V. E. Drory, G. Borghero, G. Mora, A Calvo, J. D. Rothstein, Italsgen, C. Drepper, M. Sendtner, A. B. Singleton, J. P. Taylor, M. R. Cookson, G. Restagno, M. Sabatelli, R. Bowser, A. Chio, B. J. Traynor, Nat. Neurosci. 2014, 17, 664, DOI: 10.1038/nn.3688.

[14] H. J. Kim, N. C. Kim, Y. D. Wang, E. A. Scarborough, J. Moore, Z. Diaz, K. S. MacLea, B. Freibaum, S. Li, A. Molliex, A. P. Kanagaraj, R. Carter, K. B. Boylan, A. M. Wojtas, R. Rademakers, J. L. Pinkus, S. A. Greenberg, J. Q. Trojanowski, B. J. Traynor, B. N. Smith, S. Topp, A. S. Gkazi, J. Miller, C. E. Shaw, M. Kottlors, J. Kirschner, A. Pestronk, Y. R. Li, A. F. Ford, A D. Gitler, M. Benatar, O. D. King, V. E. Kimonis, E. D. Ross, C. C. Weihl, J. Shorter, J. P. Taylor, Nature 2013, 495, 467, DOI: 10.1038/nature11922.

[15] M. DeJesus-Hernandez, I. R. Mackenzie, B. F. Boeve, A. L. Boxer, M. Baker, N. J. Rutherford, A. M. Nicholson, N. A. Finch, H. Flynn, J. Adamson, N. Kouri, A. Wojtas, P. Sengdy, G.-Y. R. Hsiung, A. Karydas, W. W. Seeley, K. A. Josephs, G. Coppola, D. H. Geschwind, Z. K. Wszolek, H. Feldman, D. 
S. Knopman, R. C. Petersen, B. L. Miller, D. W. Dickson, K. B. Boylan, N. R. Graff-Radford, R. Rademakers, Neuron 2011, 72, 245.

[16] S. H. Ou, F. Wu, D. Harrich, L. F. Garcia-Martinez, R. B. Gaynor, J. Virol. 1995, 69, 3584

[17] J. Nehls, H. Koppensteiner, R. Brack-Werner, T. Floss, M. Schindler, PLoS One 2014, 9, e105478, DOI: 10.1371/journal.pone.0105478.

[18] M. M. Abhyankar, C. Urekar, P. P. Reddi, J. Biol. Chem. 2007, 282, 36143, DOI: $10.1074 /$ jbc.M705811200.

[19] A. S. Lalmansingh, C. J. Urekar, P. P. Reddi, J. Biol. Chem. 2011, 286, 10970, DOI: 10.1074/jbc.M110.166587.

[20] a) I. Casafont, R. Bengoechea, O. Tapia, M. T. Berciano, M. Lafarga, $J$. Struct. Biol. 2009, 167, 235, DOI: 10.1016/j.jsb.2009.06.006; b) J. R. Thorpe, H. Tang, J. Atherton, N. J. Cairns, J. Neural. Transm. (Vienna) 2008, 115, 1661, DOI: 10.1007/s00702-008-0137-1.

[21] a) E. Buratti, T. Dork, E. Zuccato, F. Pagani, M. Romano, F. E. Baralle, EMBO J. 2001, 20, 1774, DOI: 10.1093/emboj/20.7.1774; b) E. Buratti, A. Brindisi, M. Giombi, S. Tisminetzky, Y. M. Ayala, F. E. Baralle, J. Biol. Chem. 2005, 280, 37572, DOI: 10.1074/jbc.M505557200.

[22] a) M. Polymenidou, C. Lagier-Tourenne, K. R. Hutt, S. C. Huelga, J. Moran, T. Y. Liang, S. C. Ling, E. Sun, E. Wancewicz, C. Mazur, H. Kordasiewicz, Y. Sedaghat, J. P. Donohue, L. Shiue, C. F. Bennett, G. W. Yeo, D. W. Cleveland, Nat. Neurosci. 2011, 14, 459, DOI: 10.1038/nn.2779; b) J. R. Tollervey, T. Curk, B. Rogelj, M. Briese, M. Cereda, M. Kayikci, J. Konig, T. Hortobagyi, A. L. Nishimura, V. Zupunski, R. Patani, S. Chandran, G. Rot, B. Zupan, C. E. Shaw, J. Ule, Nat. Neurosci. 2011, 14, 452, DOI: $10.1038 / \mathrm{nn} .2778$.

[23] M. Polymenidou, C. Lagier-Tourenne, K. R. Hutt, C. F. Bennett, D. W. Cleveland, G. W. Yeo, Brain Res. 2012, 1462, 3, DOI: 10.1016/j. brainres.2012.02.059.

[24] Y. M. Ayala, S. Pantano, A. D’Ambrogio, E. Buratti, A. Brindisi, C. Marchetti, M. Romano, F. E. Baralle, J. Mol. Biol. 2005, 348, 575, DOI: 10.1016/j.jmb.2005.02.038.

[25] P. J. Lukavsky, D. Daujotyte, J. R. Tollervey, J. Ule, C. Stuani, E. Buratti, F. E. Baralle, F. F. Damberger, F. H. Allain, Nat. Struct. Mol. Biol. 2013, 20, 1443, DOI: $10.1038 / \mathrm{nsmb} .2698$.

[26] J. P. Ling, O. Pletnikova, J. C. Troncoso, P. C. Wong, Science 2015, 349, 650, DOI: $10.1126 /$ science. aab0983.

[27] Z. Melamed, J. Lopez-Erauskin, M. W. Baughn, O. Zhang, K. Drenner, Y. Sun, F. Freyermuth, M. A. McMahon, M. S. Beccari, J. W. Artates, T. Ohkubo, M. Rodriguez, N. Lin, D. Wu, C. F. Bennett, F. Rigo, S. Da Cruz, J. Ravits, C. Lagier-Tourenne, D. W. Cleveland, Nat. Neurosci. 2019, 22, 180, DOI: 10.1038/s41593-018-0293-Z.

[28] Y. Kawahara, A. Mieda-Sato, Proc. Natl. Acad. Sci. USA 2012, 109, 3347, DOI: $10.1073 /$ pnas.1112427109.

[29] X. Chen, Z. Fan, W. McGee, M. Chen, R. Kong, P. Wen, T. Xiao, X. Chen, J. Liu, L. Zhu, R. Chen, J. Y. Wu, Protein Cell 2017, DOI: 10.1007/s13238017-0480-9.

[30] Y. M. Ayala, P. Zago, A. D’Ambrogio, Y. F. Xu, L. Petrucelli, E. Buratti, F. E. Baralle, J. Cell Sci. 2008, 121, 3778, DOI: 10.1242/jcs.038950.

[31] S. J. Barmada, G. Skibinski, E. Korb, E. J. Rao, J. Y. Wu, S. Finkbeiner, J. Neurosci. 2010, 30, 639, DOI: 10.1523/JNEUROSCI.4988-09.2010.

[32] a) C. Lagier-Tourenne, M. Polymenidou, D. W. Cleveland, Hum. Mol. Genet. 2010, 19, R46, DOI: 10.1093/hmg/ddq137; b) S. E. Avendano-Vazquez, A. Dhir, S. Bembich, E. Buratti, N. Proudfoot, F. E. Baralle, Genes Dev. 2012, 26, 1679, DOI: 10.1101/gad.194829.112.

[33] Y. M. Ayala, L. De Conti, S. E. Avendano-Vazquez, A. Dhir, M. Romano, A. D’Ambrogio, J. Tollervey, J. Ule, M. Baralle, E. Buratti, F. E. Baralle, EMBO J. 2011, 30, 277, DOI: 10.1038/emboj.2010.310.

[34] S. D'Alton, M. Altshuler, J. Lewis, RNA 2015, 21, 1419, DOI: 10.1261/ rna.047647.114.

[35] H. Ederle, D. Dormann, FEBS Lett. 2017, 591, 1489, DOI: 10.1002/18733468.12646 .

[36] a) B. D. Freibaum, R. K. Chitta, A. A. High, J. P. Taylor, J. Proteome Res. 2010, 9, 1104, DOI: 10.1021/pr901076y; b) S. C. Ling, C. P. Albuquerque, J. S. Han, C. Lagier-Tourenne, S. Tokunaga, H. Zhou, D. W. Cleveland, Proc. Natl. Acad. Sci. USA 2010, 107, 13318, DOI: 10.1073/pnas.1008227107.

[37] a) C. Fallini, G. J. Bassell, W. Rossoll, Hum. Mol. Genet. 2012, 21, 3703, DOI: $10.1093 / \mathrm{hmg} / \mathrm{dds} 205$; b) N. H. Alami, R. B. Smith, M. A. Carrasco, L. A. Williams, C. S. Winborn, S. S. W. Han, E. Kiskinis, B. Winborn, B. D. Freibaum, A. Kanagaraj, A. J. Clare, N. M. Badders, B. Bilican, E. Chaum, S. Chandran, C. E. Shaw, K. C. Eggan, T. Maniatis, J. P. Taylor, Neuron 2014, 81, 536, DOI: 10.1016/j.neuron.2013.12.018.

[38] a) C. Colombrita, E. Zennaro, C. Fallini, M. Weber, A. Sommacal, E. Buratti, V. Silani, A. Ratti, J. Neurochem. 2009, 111, 1051, DOI: 10.1111/j.14714159.2009.06383.x; b) C. M. Dewey, B. Cenik, C. F. Sephton, D. R. Dries, P. Mayer, 3rd, S. K. Good, B. A. Johnson, J. Herz, G. Yu, Mol. Cell Biol. 2011, 31, 1098, DOI: 10.1128/MCB.01279-10.

[39] a) A. Molliex, J. Temirov, J. Lee, M. Coughlin, A. P. Kanagaraj, H. J. Kim, T. Mittag, J. P. Taylor, Cell 2015, 163, 123, DOI: 10.1016/j.cell.2015.09.015; b) Y. R. Li, O. D. King, J. Shorter, A. D. Gitler, J. Cell Biol. 2013, 201, 361, DOI: $10.1083 /$ jcb.201302044.
[40] T. Ota, Y. Suzuki, T. Nishikawa, T. Otsuki, T. Sugiyama, R. Irie, A. Wakamatsu, K. Hayashi, H. Sato, K. Nagai, K. Kimura, H. Makita, M. Sekine, M. Obayashi, T. Nishi, T. Shibahara, T. Tanaka, S. Ishii, J. Yamamoto, K. Saito, Y. Kawai, Y. Isono, Y. Nakamura, K. Nagahari, K. Murakami, T. Yasuda, T. Iwayanagi, M. Wagatsuma, A. Shiratori, H. Sudo, T. Hosoiri, Y. Kaku, H. Kodaira, H. Kondo, M. Sugawara, M. Takahashi, K. Kanda, T. Yokoi, T. Furuya, E. Kikkawa, Y. Omura, K. Abe, K. Kamihara, N. Katsuta, K. Sato, M. Tanikawa, M. Yamazaki, K. Ninomiya, T. Ishibashi, H. Yamashita, K. Murakawa, K. Fujimori, H. Tanai, M. Kimata, M. Watanabe, S. Hiraoka, Y. Chiba, S. Ishida, Y. Ono, S. Takiguchi, S. Watanabe, M. Yosida, T. Hotuta, J. Kusano, K. Kanehori, A. Takahashi-Fujii, H. Hara, T. O. Tanase, Y. Nomura, S. Togiya, F. Komai, R. Hara, K. Takeuchi, M. Arita, N. Imose, K. Musashino, H. Yuuki, A. Oshima, N. Sasaki, S. Aotsuka, Y. Yoshikawa, H. Matsunawa, T. Ichihara, N. Shiohata, S. Sano, S. Moriya, H. Momiyama, N. Satoh, S. Takami, Y. Terashima, O. Suzuki, S. Nakagawa, A. Senoh, H. Mizoguchi, Y. Goto, F. Shimizu, H. Wakebe, H. Hishigaki, T. Watanabe, A. Sugiyama, M. Takemoto, B. Kawakami, M. Yamazaki, K. Watanabe, A. Kumagai, S. Itakura, Y. Fukuzumi, Y. Fujimori, M. Komiyama, H. Tashiro, A. Tanigami, T. Fujiwara, T. Ono, K. Yamada, Y. Fujii, K. Ozaki, M. Hirao, Y. Ohmori, A. Kawabata, T. Hikiji, N. Kobatake, H. Inagaki, Y. Ikema, S. Okamoto, R. Okitani, T. Kawakami, S. Noguchi, T. Itoh, K. Shigeta, T. Senba, K. Matsumura, Y. Nakajima, T. Mizuno, M. Morinaga, M. Sasaki, T. Togashi, M. Oyama, H. Hata, M. Watanabe, T. Komatsu, J. MizushimaSugano, T. Satoh, Y. Shirai, Y. Takahashi, K. Nakagawa, K. Okumura, T. Nagase, N. Nomura, H. Kikuchi, Y. Masuho, R. Yamashita, K. Nakai, T. Yada, Y. Nakamura, O. Ohara, T. Isogai, S. Sugano, Nat. Genet. 2004, 36 40, DOI: $10.1038 / \mathrm{ng} 1285$

[41] T. Afroz, Z. Cienikova, A. Clery, F. H. Allain, Methods Enzymol. 2015, 558, 235, DOI: 10.1016/bs.mie.2015.01.015.

[42] T. Afroz, E. M. Hock, P. Ernst, C. Foglieni, M. Jambeau, L. A. B. Gilhespy, F. Laferriere, Z. Maniecka, A. Pluckthun, P. Mittl, P. Paganetti, F. H. T. Allain, M. Polymenidou, Nat. Commun. 2017, 8, 45, DOI: 10.1038/s41467017-00062-0.

[43] M. J. Winton, L. M. Igaz, M. M. Wong, L. K. Kwong, J. Q. Trojanowski, V. M. Lee, J. Biol. Chem. 2008, 283, 13302, DOI: 10.1074/jbc.M800342200.

[44] H. Ederle, C. Funk, C. Abou-Ajram, S. Hutten, E. B. E. Funk, R. H. Kehlenbach, S. M. Bailer, D. Dormann, Sci. Rep. 2018, 8, 7084, DOI: 10.1038/s41598-018-25007-5.

[45] E. M. Hock, Z. Maniecka, M. Hruska-Plochan, S. Reber, F. Laferriere, M. K. S. Sahadevan, H. Ederle, L. Gittings, L. Pelkmans, L. Dupuis, T. Lashley, M. D. Ruepp, D. Dormann, M. Polymenidou, Cell Rep. 2018, 24, 987, DOI: 10.1016/j.celrep.2018.06.094

[46] Y. Shiina, K. Arima, H. Tabunoki, J. Satoh, Cell Mol. Neurobiol. 2010, 30 641, DOI: 10.1007/s10571-009-9489-9.

[47] a) C. K. Chang, T. H. Wu, C. Y. Wu, M. H. Chiang, E. K. Toh, Y. C. Hsu, K. F. Lin, Y. H. Liao, T. H. Huang, J. J. Huang, Biochem. Biophys. Res. Commun. 2012, 425, 219, DOI: 10.1016/j.bbrc.2012.07.071; b) Y. J. Zhang, T. Caulfield, Y. F. Xu, T. F. Gendron, J. Hubbard, C. Stetler, H. Sasaguri, E. C. Whitelaw, S. Cai, W. C. Lee, L. Petrucelli, Hum. Mol. Genet. 2013, 22, 3112, DOI: $10.1093 / \mathrm{hmg} / \mathrm{ddt} 166$.

[48] H. Qin, L. Z. Lim, Y. Wei, J. Song, Proc. Natl. Acad. Sci. USA 2014, 111, 18619, DOI: 10.1073/pnas.1413994112.

[49] M. Mompean, V. Romano, D. Pantoja-Uceda, C. Stuani, F. E. Baralle, E. Buratti, D. V. Laurents, FEBS J. 2016, 283, 1242, DOI: 10.1111/febs.13651.

[50] a) P. S. Tsoi, K. J. Choi, P. G. Leonard, A. Sizovs, M. M. Moosa, K. R. MacKenzie, J. C. Ferreon, A. C. M. Ferreon, Angew. Chem. Int. Ed. 2017 DOI: 10.1002/anie.201706769; b) A. Wang, A. E. Conicella, H. B. Schmidt, E. W. Martin, S. N. Rhoads, A. N. Reeb, A. Nourse, D. Ramirez Montero, V. H. Ryan, R. Rohatgi, F. Shewmaker, M. T. Naik, T. Mittag, Y. M. Ayala, N. L. Fawzi, EMBO J. 2018, 37, DOI: 10.15252/embj.201797452.

[51] A. Ishiguro, N. Kimura, Y. Watanabe, S. Watanabe, A. Ishihama, Genes Cells 2016, 21, 466, DOI: $10.1111 /$ gtc. 12352.

[52] P. H. Kuo, C. H. Chiang, Y. T. Wang, L. G. Doudeva, H. S. Yuan, Nucleic Acids Res. 2014, 42, 4712, DOI: 10.1093/nar/gkt1407.

[53] P. H. Kuo, L. G. Doudeva, Y. T. Wang, C. K. Shen, H. S. Yuan, Nucleic Acids Res. 2009, 37, 1799, DOI: 10.1093/nar/gkp013.

[54] T. Afroz, L. Skrisovska, E. Belloc, J. Guillen-Boixet, R. Mendez, F. H. T. Allain, Gene Dev. 2014, 28, 1498, DOI: 10.1101/gad.241133.114.

[55] a) Y. C. Huang, K. F. Lin, R. Y. He, P. H. Tu, J. Koubek, Y. C. Hsu, J. J. Huang, PLoS One 2013, 8, e64002, DOI: 10.1371/journal.pone.0064002; b) T. J. Cohen, A. W. Hwang, C. R. Restrepo, C. X. Yuan, J. Q. Trojanowski, V. M. Lee, Nat. Commun. 2015, 6, 5845, DOI: 10.1038/ncomms6845.

[56] a) S. Maharana, J. Wang, D. K. Papadopoulos, D. Richter, A. Pozniakovsky, I. Poser, M. Bickle, S. Rizk, J. Guillen-Boixet, T. M. Franzmann, M. Jahnel, L. Marrone, Y. T. Chang, J. Sterneckert, P. Tomancak, A. A. Hyman, S. Alberti, Science 2018, 360, 918, DOI: 10.1126/science.aar7366; b) E. M. Langdon, Y. Qiu, A. Ghanbari Niaki, G. A. McLaughlin, C. A. Weidmann, T. M. Gerbich, J. A. Smith, J. M. Crutchley, C. M. Termini, K. M. Weeks, S. Myong, A. S. Gladfelter, Science 2018, 360, 922, DOI: 10.1126/science. aar7432; c) M. Polymenidou, Science 2018, 360, 859, DOI: $10.1126 / \mathrm{sci}-$ ence.aat 8028 
[57] P. Wang, C. M. Wander, C. X. Yuan, M. S. Bereman, T. J. Cohen, Nat. Commun. 2017, 8, 82, DOI: 10.1038/s41467-017-00088-4.

[58] W. Li, A. N. Reeb, B. Lin, P. Subramanian, E. E. Fey, C. R. Knoverek, R. L. French, E. H. Bigio, Y. M. Ayala, J. Biol. Chem. 2017, 292, 5089, DOI: 10.1074/jbc.M116.753913.

[59] a) L. L. Jiang, J. Zhao, X. F. Yin, W. T. He, H. Yang, M. X. Che, H. Y. Hu, Sci. Rep. 2016, 6, 23928, DOI: 10.1038/srep23928; b) L. Lim, Y. Wei, Y. Lu, J. Song, PLoS Biol. 2016, 14, e1002338, DOI: 10.1371/journal.pbio.1002338; c) A. E. Conicella, G. H. Zerze, J. Mittal, N. L. Fawzi, Structure 2016, 24, 1537, DOI: $10.1016 /$ j.str.2016.07.007

[60] M. Mompean, R. Hervas, Y. Xu, T. H. Tran, C. Guarnaccia, E. Buratti, F. Baralle, L. Tong, M. Carrion-Vazquez, A. E. McDermott, D. V. Laurents, $J$. Phys. Chem. Lett. 2015, 6, 2608, DOI: 10.1021/acs.jpclett.5b00918.

[61] E. L. Guenther, Q. Cao, H. Trinh, J. Lu, M. R. Sawaya, D. Cascio, D. R. Boyer, J. A. Rodriguez, M. P. Hughes, D. S. Eisenberg, Nat. Struct. Mol. Biol. 2018, 25, 463, DOI: 10.1038/s41594-018-0064-2.

[62] J. C. Schwartz, X. Wang, E. R. Podell, T. R. Cech, Cell Rep. 2013, 5, 918, DOI: 10.1016/j.celrep.2013.11.017.

[63] A. Kitamura, Y. Nakayama, A. Shibasaki, A. Taki, S. Yuno, K. Takeda, M. Yahara, N. Tanabe, M. Kinjo, Sci. Rep. 2016, 6, 19230, DOI: 10.1038/ srep19230.

[64] E. B. Dammer, C. Fallini, Y. M. Gozal, D. M. Duong, W. Rossoll, P. Xu, J. J. Lah, A. I. Levey, J. Peng, G. J. Bassell, N. T. Seyfried, PLoS One 2012, 7, e38658, DOI: 10.1371/journal.pone.0038658.

[65] a) M. Kato, T. W. Han, S. Xie, K. Shi, X. Du, L. C. Wu, H. Mirzaei, E. J. Goldsmith, J. Longgood, J. Pei, N. V. Grishin, D. E. Frantz, J. W. Schneider, S. Chen, L. Li, M. R. Sawaya, D. Eisenberg, R. Tycko, S. L. McKnight, Cell 2012, 149, 753, DOI: 10.1016/j.cell.2012.04.017; b) F. Gasset-Rosa, S. Lu, H. Yu, C. Chen, Z. Melamed, L. Guo, J. Shorter, S. Da Cruz, D. W. Cleveland, Neuron 2019, DOI: 10.1016/j.neuron.2019.02.038; c) J. R. Mann, A. M. Gleixner, J. C. Mauna, E. Gomes, M. R. DeChellis-Marks, P. G. Needham, K. E. Copley, B. Hurtle, B. Portz, N. J. Pyles, L. Guo, C. B Calder, Z. P. Wills, U. B. Pandey, J. K. Kofler, J. L. Brodsky, A. Thathiah, J. Shorter, C. J. Donnelly, Neuron 2019, DOI: 10.1016/j.neuron.2019.01.048.

[66] T. W. Han, M. Kato, S. Xie, L. C. Wu, H. Mirzaei, J. Pei, M. Chen, Y. Xie, J. Allen, G. Xiao, S. L. McKnight, Cell 2012, 149, 768, DOI: 10.1016/j. cell.2012.04.016.

[67] E. L. Scotter, H. J. Chen, C. E. Shaw, Neurotherapeutics 2015, 12, 352, DOI 10.1007/s13311-015-0338-X.

[68] a) S. H. Freeman, T. Spires-Jones, B. T. Hyman, J. H. Growdon, M. P. Frosch, J. Neuropathol. Exp. Neurol. 2008, 67, 62, DOI: 10.1097/ nen.0b013e3181609361; b)H. Fujishiro, H. Uchikado, T.Arai, M. Hasegawa, H. Akiyama, O. Yokota, K. Tsuchiya, T. Togo, E. Iseki, Y. Hirayasu, Acta Neuropathol. 2009, 117, 151, DOI: 10.1007/s00401-008-0463-2; c) C. Schwab, T. Arai, M. Hasegawa, S. Yu, P. L. McGeer, J. Neuropathol. Exp. Neurol. 2008, 67, 1159, DOI: 10.1097/NEN.0b013e31818e8951; d) K. Uryu, H. Nakashima-Yasuda, M. S. Forman, L. K. Kwong, C. M. Clark, M. Grossman, B. L. Miller, H. A. Kretzschmar, V. M. Lee, J. Q. Trojanowski, M. Neumann, J. Neuropathol. Exp. Neurol. 2008, 67, 555, DOI: $10.1097 /$ NEN.0b013e31817713b5; e) H. Nakashima-Yasuda, K. Uryu, J. Robinson, S. X. Xie, H. Hurtig, J. E. Duda, S. E. Arnold, A. Siderowf, M. Grossman, J. B. Leverenz, R. Woltjer, O. L. Lopez, R. Hamilton, D. W. Tsuang, D. Galasko, E. Masliah, J. Kaye, C. M. Clark, T. J. Montine, V. M. Lee, J. Q. Trojanowski, Acta Neuropathol. 2007, 114, 221, DOI: 10.1007/s00401007-0261-2; f) C. Amador-Ortiz, W. L. Lin, Z. Ahmed, D. Personett, P. Davies, R. Duara, N. R. Graff-Radford, M. L. Hutton, D. W. Dickson, Ann. Neurol. 2007, 61, 435, DOI: 10.1002/ana.21154; gS. Higashi, E. Iseki, R. Yamamoto, M. Minegishi, H. Hino, K. Fujisawa, T. Togo, O. Katsuse, H. Uchikado, Y. Furukawa, K. Kosaka, H. Arai, Brain Res. 2007, 1184, 284, DOI: 10.1016/j.brainres.2007.09.048.

[69] a) M. Hasegawa, T. Arai, H. Akiyama, T. Nonaka, H. Mori, T. Hashimoto, M. Yamazaki, K. Oyanagi, Brain 2007, 130, 1386, DOI: 10.1093/brain/ awm065; b) F. Geser, M. J. Winton, L. K. Kwong, Y. Xu, S. X. Xie, L. M. Igaz, R. M. Garruto, D. P. Perl, D. Galasko, V. M. Lee, J. Q. Trojanowski, Acta Neuropathol. 2008, 115, 133, DOI: 10.1007/s00401-007-0257-y; c) S. Maekawa, P. N. Leigh, A. King, E. Jones, J. C. Steele, I. Bodi, C. E. Shaw, T. Hortobagyi, S. Al-Sarraj, Neuropathology 2009, 29, 672, DOI: 10.1111/j.1440-1789.2009.01029.x.

[70] a) M. T. Giordana, M. Piccinini, S. Grifoni, G. De Marco, M. Vercellino, M Magistrello, A. Pellerino, B. Buccinna, E. Lupino, M. T. Rinaudo, Brain Pathol. 2010, 20, 351, DOI: 10.1111/j.1750-3639.2009.00284.x; b) H. Zhou, C. Huang, H. Chen, D. Wang, C. P. Landel, P. Y. Xia, R. Bowser, Y. J. Liu, X. G. Xia, PLoS Genet. 2010, 6, e1000887, DOI: 10.1371/journal. pgen. 1000887.

[71] a) L. S. Wu, W. C. Cheng, S. C. Hou, Y. T. Yan, S. T. Jiang, C. K. Shen, Genesis 2010, 48, 56, DOI: 10.1002/dvg.20584; b) C. F. Sephton, S. K. Good, S. Atkin, C. M. Dewey, P. Mayer, 3rd, J. Herz, G. Yu, J. Biol. Chem. 2010, 285, 6826, DOI: 10.1074/jbc.M109.061846; c) B. C. Kraemer, T. Schuck, J. M. Wheeler, L. C. Robinson, J. Q. Trojanowski, V. M. Lee, G. D. Schellenberg, Acta Neuropathol. 2010, 119, 409, DOI: 10.1007/s00401010-0659-0.
[72] a) C. Yang, H. Wang, T. Qiao, B. Yang, L. Aliaga, L. Qiu, W. Tan, J. Salameh, D. M. McKenna-Yasek, T. Smith, L. Peng, M. J. Moore, R. H. Brown, Jr., H. Cai, Z. Xu, Proc. Natl. Acad. Sci. USA 2014, 111, E1121, DOI: 10.1073/ pnas.1322641111; b) E. S. Arnold, S. C. Ling, S. C. Huelga, C. LagierTourenne, M. Polymenidou, D. Ditsworth, H. B. Kordasiewicz, M. McAlonisDownes, O. Platoshyn, P. A. Parone, S. Da Cruz, K. M. Clutario, D. Swing, L. Tessarollo, M. Marsala, C. E. Shaw, G. W. Yeo, D. W. Cleveland, Proc. Natl. Acad. Sci. USA 2013, 110, E736, DOI: 10.1073/pnas.1222809110.

[73] J. Gu, F. Chen, K. Iqbal, C. X. Gong, X. Wang, F. Liu, J. Biol. Chem. 2017, 292, 10600, DOI: 10.1074/jbc.M117.783498.

[74] T. Tian, C. Huang, J. Tong, M. Yang, H. Zhou, X. G. Xia, Int. J. Biol. Sci. 2011, 7, 234.

[75] a) H. J. Wobst, S. S. Wesolowski, J. Chadchankar, L. Delsing, S. Jacobsen, J. Mukherjee, T. Z. Deeb, J. Dunlop, N. J. Brandon, S. J. Moss, Front. Mol. Neurosci. 2017, 10, 46, DOI: 10.3389/fnmol.2017.00046; b) P. M. Chiang, J. Ling, Y. H. Jeong, D. L. Price, S. M. Aja, P. C. Wong, Proc. Natl. Acad. Sci. USA 2010, 107, 16320, DOI: 10.1073/pnas.1002176107; c) Y. Iguchi, M. Katsuno, J. Niwa, S. Takagi, S. Ishigaki, K. Ikenaka, K. Kawai, H. Watanabe, K. Yamanaka, R. Takahashi, H. Misawa, S. Sasaki, F. Tanaka, G. Sobue, Brain 2013, 136, 1371, DOI: 10.1093/brain/awt029.

[76] R. H. Baloh, FEBS J. 2011, 278, 3539, DOI: 10.1111/j.1742 4658.2011.08256.x.

[77] a) M. Neumann, I. R. Mackenzie, N. J. Cairns, P. J. Boyer, W. R. Markesbery, C. D. Smith, J. P. Taylor, H. A. Kretzschmar, V. E. Kimonis, M. S. Forman, J. Neuropathol. Exp. Neurol. 2007, 66, 152, DOI: 10.1097/ nen.0b013e31803020b9; b) M. Hasegawa, T. Arai, T. Nonaka, F. Kametani, M. Yoshida, Y. Hashizume, T. G. Beach, E. Buratti, F. Baralle, M. Morita, I Nakano, T. Oda, K. Tsuchiya, H. Akiyama, Ann. Neurol. 2008, 64, 60, DOI: 10.1002/ana.21425

[78] a) M. Neumann, L. K. Kwong, D. M. Sampathu, J. Q. Trojanowski, V. M. Lee, Arch. Neurol. 2007, 64, 1388, DOI: 10.1001/archneur.64.10.1388, b) A. Kerman, H. N. Liu, S. Croul, J. Bilbao, E. Rogaeva, L. Zinman, J. Robertson, A. Chakrabartty, Acta Neuropathol. 2010, 119, 335, DOI: 10.1007/s00401-010-0646-5.

[79] C. Capitini, S. Conti, M. Perni, F. Guidi, R. Cascella, A. De Poli, A. Penco, A Relini, C. Cecchi, F. Chiti, Plos One 2014, 9, DOI: ARTN e8672010.1371/ journal.pone.0086720.

[80] a) N. J. Cairns, M. Neumann, E. H. Bigio, I. E. Holm, D. Troost, K. J. Hatanpaa, C. Foong, C. L. White, 3rd, J. A. Schneider, H. A. Kretzschmar, D. Carter, L. Taylor-Reinwald, K. Paulsmeyer, J. Strider, M. Gitcho, A. M. Goate, J. C. Morris, M. Mishra, L. K. Kwong, A. Stieber, Y. Xu, M. S. Forman, J. Q. Trojanowski, V. M. Lee, I. R. Mackenzie, Am. J. Pathol. 2007, 171, 227, DOI: 10.2353/ajpath.2007.070182; b) W. L. Lin, D. W. Dickson, Acta Neuropathol. 2008, 116, 205, DOI: 10.1007/s00401-008-0408-9; c) F. Mori, K. Tanji, H. X. Zhang, Y. Nishihira, C. F. Tan, H. Takahashi, K. Wakabayashi, Acta Neuropathol. 2008, 116, 193, DOI: 10.1007/s00401008-0396-9.

[81] J. L. Robinson, F. Geser, A. Stieber, M. Umoh, L. K. Kwong, V. M. Van Deerlin, V. M. Lee, J. Q. Trojanowski, Acta Neuropathol. 2013, 125, 121, DOI: 10.1007/s00401-012-1055-8.

[82] Y. S. Fang, K. J. Tsai, Y. J. Chang, P. Kao, R. Woods, P. H. Kuo, C. C. Wu, J. Y. Liao, S. C. Chou, V. Lin, L. W. Jin, H. S. Yuan, I. H. Cheng, P. H. Tu, Y. R. Chen, Nat. Commun. 2014, 5, 4824, DOI: 10.1038/ncomms5824.

[83] E. L. Guenther, P. Ge, H. Trinh, M. R. Sawaya, D. Cascio, D. R. Boyer, T. Gonen, Z. H. Zhou, D. S. Eisenberg, Nat. Struct. Mol. Biol. 2018, 25, 311 , DOI: $10.1038 / \mathrm{s} 41594-018-0045-5$.

[84] F. Laferriere, Z. Maniecka, M. Perez-Berlanga, M. Hruska-Plochan, L. Gilhespy, E. M. Hock, U. Wagner, T. Afroz, P. J. Boersema, G. Barmettler, S. C. Foti, Y. T. Asi, A. M. Isaacs, A. Al-Amoudi, A. Lewis, H. Stahlberg, J. Ravits, F. De Giorgi, F. Ichas, E. Bezard, P. Picotti, T. Lashley, M. Polymenidou, Nat. Neurosci. 2019, 22, 65, DOI: 10.1038/s41593-0180294-y.

[85] a) H. Tsuji, T. Arai, F. Kametani, T. Nonaka, M. Yamashita, M. Suzukake, M. Hosokawa, M. Yoshida, H. Hatsuta, M. Takao, Y. Saito, S. Murayama, H. Akiyama, M. Hasegawa, D. M. Mann, A. Tamaoka, Brain 2012, 135, 3380, DOI: 10.1093/brain/aws230; b) I. R. Mackenzie, M. Neumann, Acta Neuropathol. 2017, 134, 79, DOI: 10.1007/s00401-017-1716-8; c) E. B. Lee, S. Porta, G. Michael Baer, Y. Xu, E. Suh, L. K. Kwong, L. Elman, M. Grossman, V. M. Lee, D. J. Irwin, V. M. Van Deerlin, J. Q. Trojanowski, Acta Neuropathol. 2017, 134, 65, DOI: 10.1007/s00401-017-1679-9.

[86] F. Kametani, T. Obi, T. Shishido, H. Akatsu, S. Murayama, Y. Saito, M. Yoshida, M. Hasegawa, Sci. Rep. 2016, 6, 23281, DOI: 10.1038/srep23281.

[87] Y. J. Zhang, Y. F. Xu, C. A. Dickey, E. Buratti, F. Baralle, R. Bailey, S. Pickering-Brown, D. Dickson, L. Petrucelli, J. Neurosci. 2007, 27, 10530 DOI: 10.1523/JNEUROSCI.3421-07.2007.

[88] a) Q. Li, M. Yokoshi, H. Okada, Y. Kawahara, Nat. Commun. 2015, 6, 6183, DOI: 10.1038/ncomms7183; b) Y. J. Zhang, Y. F. Xu, C. Cook, T. F. Gendron, P. Roettges, C. D. Link, W. L. Lin, J. Tong, M. Castanedes-Casey, P. Ash, J. Gass, V. Rangachari, E. Buratti, F. Baralle, T. E. Golde, D. W. Dickson, L. Petrucelli, Proc. Natl. Acad. Sci. USA 2009, 106, 7607, DOI: 10.1073/pnas.0900688106. 
[89] T. Nonaka, F. Kametani, T. Arai, H. Akiyama, M. Hasegawa, Hum. Mol. Genet. 2009, 18, 3353, DOI: $10.1093 / \mathrm{hmg} / \mathrm{ddp} 275$.

[90] a) H. J. Wobst, L. Delsing, N. J. Brandon, S. J. Moss, PLoS One 2017, 12, e0177181, DOI: 10.1371/journal.pone.0177181; b) C. H. Chiang, C. Grauffel, L. S. Wu, P. H. Kuo, L. G. Doudeva, C. Lim, C. K. Shen, H. S. Yuan, Sci. Rep. 2016, 6, 21581, DOI: 10.1038/srep21581; c) E. Kabashi, P. N. Valdmanis, P. Dion, D. Spiegelman, B. J. McConkey, C. Vande Velde, J. P. Bouchard, L. Lacomblez, K. Pochigaeva, F. Salachas, P. F. Pradat, W. Camu, V. Meininger, N. Dupre, G. A. Rouleau, Nat. Genet. 2008, 40, 572, DOI: $10.1038 / \mathrm{ng} .132$

[91] T. F. Gendron, R. Rademakers, L. Petrucelli, J. Alzheimers Dis. 2013, 33 Suppl 1, S35, DOI: 10.3233/JAD-2012-129036.

[92] N. T. Seyfried, Y. M. Gozal, E. B. Dammer, Q. Xia, D. M. Duong, D. Cheng, J. J. Lah, A. I. Levey, J. Peng, Mol. Cell Proteomics 2010, 9, 705, DOI: 10.1074/mcp.M800390-MCP200.

[93] a) J. H. Hu, H. Zhang, R. Wagey, C. Krieger, S. L. Pelech, J. Neurochem. 2003, 85, 432; b) F. Krach, R. Batra, E. C. Wheeler, A. Q. Vu, R. Wang, K. Hutt, S. J. Rabin, M. W. Baughn, R. T. Libby, S. Diaz-Garcia, J. Stauffer, E. Pirie, S. Saberi, M. Rodriguez, A. A. Madrigal, Z. Kohl, B. Winner, G. W. Yeo, J. Ravits, Acta Neuropathol. 2018, 136, 405, DOI: 10.1007/s00401018-1870-7.

[94] T. Nonaka, G. Suzuki, Y. Tanaka, F. Kametani, S. Hirai, H. Okado, T. Miyashita, M. Saitoe, H. Akiyama, H. Masai, M. Hasegawa, J. Biol. Chem. 2016, 291, 5473, DOI: 10.1074/jbc.M115.695379.

[95] D. K. Choksi, B. Roy, S. Chatterjee, T. Yusuff, M. F. Bakhoum, U. Sengupta, S. Ambegaokar, R. Kayed, G. R. Jackson, Hum. Mol. Genet. 2014, 23, 1025, DOI: $10.1093 / \mathrm{hmg} / \mathrm{ddt} 498$.

[96] Y. J. Zhang, T. F. Gendron, Y. F. Xu, L. W. Ko, S. H. Yen, L. Petrucelli, Mol. Neurodegener. 2010, 5, 33, DOI: 10.1186/1750-1326-5-33.

[97] H. Y. Li, P. A. Yeh, H. C. Chiu, C. Y. Tang, B. P. Tu, PLoS One 2011, 6, e23075, DOI: 10.1371/journal.pone.0023075.

[98] N. F. Liachko, C. R. Guthrie, B. C. Kraemer, J. Neurosci. 2010, 30, 16208 , DOI: 10.1523/JNEUROSCI.2911-10.2010.

[99] a) L. Liu-Yesucevitz, A. Bilgutay, Y. J. Zhang, T. Vanderweyde, A. Citro, T. Mehta, N. Zaarur, A. McKee, R. Bowser, M. Sherman, L. Petrucelli, B. Wolozin, PLoS One 2010, 5, e13250, DOI: 10.1371/journal.pone.0013250; b) S. Prpar Mihevc, M. Baralle, E. Buratti, B. Rogelj, Sci. Rep. 2016, 6, 33996, DOI: 10.1038/srep33996.

[100] M. Neumann, L. M. Igaz, L. K. Kwong, H. Nakashima-Yasuda, S. J. Kolb, G. Dreyfuss, H. A. Kretzschmar, J. Q. Trojanowski, V. M. Lee, Acta Neuropathol. 2007, 113, 543, DOI: 10.1007/s00401-007-0221-X.

[101] L. McGurk, V. M. Lee, J. Q. Trojanowksi, V. M. Van Deerlin, E. B. Lee, N. M. Bonini, J. Neuropathol. Exp. Neurol. 2014, 73, 837, DOI: 10.1097/ NEN.0000000000000102.

[102] Y. S. Davidson, A. C. Robinson, L. Flood, S. Rollinson, B. C. Benson, Y T. Asi, A. Richardson, M. Jones, J. S. Snowden, S. Pickering-Brown, T. Lashley, D. M. A. Mann, Acta Neuropathol. Commun. 2017, 5, DOI: ARTN 5410.1186/s40478-017-0454-4.

[103] P. Zhang, B. Fan, P. Yang, J. Temirov, J. Messing, H. J. Kim, J. P. Taylor, Elife 2019, 8, DOI: 10.7554/eLife.39578.

[104] a) M. J. Winton, V. M. Van Deerlin, L. K. Kwong, W. Yuan, E. M. Wood, C. E. Yu, G. D. Schellenberg, R. Rademakers, R. Caselli, A. Karydas, J. Q. Trojanowski, B. L. Miller, V. M. Lee, FEBS Lett. 2008, 582, 2252, DOI: 10.1016/j.febslet.2008.05.024; b) F. Moreno, G. D. Rabinovici, A. Karydas, Z. Miller, S. C. Hsu, A. Legati, J. Fong, D. Schonhaut, H. Esselmann, C. Watson, M. L. Stephens, J. Kramer, J. Wiltfang, W. W. Seeley, B. L. Miller, G. Coppola, L. T. Grinberg, Acta Neuropathol. Commun. 2015, 3, 19, DOI: 10.1186/s40478-015-0190-6.

[105] a) H. Sasaguri, J. Chew, Y. F. Xu, T. F. Gendron, A. Garrett, C. W. Lee, K. Jansen-West, P. O. Bauer, E. A. Perkerson, J. Tong, C. Stetler, Y. J. Zhang, Brain Res. 2016, 1647, 57, DOI: 10.1016/j.brainres.2016.04.069; b) V. Romano, Z. Quadri, F. E. Baralle, E. Buratti, Prion 2015, 9, 1, DOI: 10.1080/19336896.2015.1011885.

[106] C. Foglieni, S. Papin, A. Salvade, T. Afroz, S. Pinton, G. Pedrioli, G. Ulrich, M. Polymenidou, P. Paganetti, Sci. Rep. 2017, 7, 14013, DOI: 10.1038/ s41598-017-14459-w.

[107] L.-L. Jiang, W. Xue, J.-Y. Hong, J.-T. Zhang, M.-J. Li, S.-N. Yu, J.-H. He, H.-Y. Hu, Sci. Rep. 2017, 7, 6196, DOI: 10.1038/s41598-017-06263-3.

[108] S. Xiao, T. Sanelli, H. Chiang, Y. Sun, A. Chakrabartty, J. Keith, E. Rogaeva, L. Zinman, J. Robertson, Acta Neuropathol. 2015, 130, 49, DOI: 10.1007/ s00401-015-1412-5.

[109] Z. Yang, F. Lin, C. S. Robertson, K. K. Wang, J. Cereb. Blood Flow Metab. 2014, 34, 1444, DOI: $10.1038 /$ jcbfm.2014.105.
[110] M. Baker, I. R. Mackenzie, S. M. Pickering-Brown, J. Gass, R. Rademakers, C. Lindholm, J. Snowden, J. Adamson, A. D. Sadovnick, S. Rollinson, A. Cannon, E. Dwosh, D. Neary, S. Melquist, A. Richardson, D. Dickson, Z. Berger, J. Eriksen, T. Robinson, C. Zehr, C. A. Dickey, R. Crook, E. McGowan, D. Mann, B. Boeve, H. Feldman, M. Hutton, Nature 2006, 442, 916, DOI: 10.1038/nature05016

[111] Y. T. Wang, P. H. Kuo, C. H. Chiang, J. R. Liang, Y. R. Chen, S. Wang, J. C. Shen, H. S. Yuan, J. Biol. Chem. 2013, 288, 9049, DOI: 10.1074/jbc. M112.438564.

[112] a) T. J. Cohen, A. W. Hwang, T. Unger, J. Q. Trojanowski, V. M. Lee, EMBO J. 2012, 31, 1241, DOI: 10.1038/emboj.2011.471; b) F. Bozzo, I. Salvatori, F. Iacovelli, A. Mirra, S. Rossi, M. Cozzolino, M. Falconi, C. Valle, M. T. Carri, Neurobiol. Dis. 2016, 94, 63, DOI: 10.1016/j.nbd.2016.06.006.

[113] C. K. Chang, M. H. Chiang, E. K. Toh, C. F. Chang, T. H. Huang, FEBS Lett. 2013, 587, 575, DOI: 10.1016/j.febslet.2013.01.038.

[114] A. Shodai, T. Morimura, A. Ido, T. Uchida, T. Ayaki, R. Takahashi, S. Kitazawa, S. Suzuki, M. Shirouzu, T. Kigawa, Y. Muto, S. Yokoyama, R. Takahashi, R. Kitahara, H. Ito, N. Fujiwara, M. Urushitani, J. Biol. Chem. 2013, 288, 14886, DOI: 10.1074/jbc.M113.451849.

[115] S. O. Rabdano, S. A. Izmailov, D. A. Luzik, A. Groves, I. S. Podkorytov, N. R. Skrynnikov, Sci. Rep. 2017, 7, 11161, DOI: 10.1038/s41598-01710574-w.

[116] L. Bargsted, D. B. Medinas, F. Martinez Traub, P. Rozas, N. Munoz, M Nassif, C. Jerez, A. Catenaccio, F. A. Court, C. Hetz, S. Matus, Sci. Rep. 2017, 7, 14266, DOI: 10.1038/s41598-017-14399-5.

[117] C. Garnier, F. Devred, D. Byrne, R. Puppo, A. Y. Roman, S. Malesinski, A. V. Golovin, R. Lebrun, N. N. Ninkina, P. O. Tsvetkov, Sci. Rep. 2017, 7, 6812, DOI: 10.1038/s41598-017-07215-7.

[118] A. Caragounis, K. A. Price, C. P. Soon, G. Filiz, C. L. Masters, Q. X. Li, P. J. Crouch, A. R. White, Free Radic. Biol. Med. 2010, 48, 1152, DOI: 10.1016/j.freeradbiomed.2010.01.035

[119] I. R. Mackenzie, A. M. Nicholson, M. Sarkar, J. Messing, M. D. Purice, C. Pottier, K. Annu, M. Baker, R. B. Perkerson, A. Kurti, B. J. Matchett, T. Mittag, J. Temirov, G. R. Hsiung, C. Krieger, M. E. Murray, M. Kato, J. D. Fryer, L. Petrucelli, L. Zinman, S. Weintraub, M. Mesulam, J. Keith, S. A. Zivkovic, V. Hirsch-Reinshagen, R. P. Roos, S. Zuchner, N. R. GraffRadford, R. C. Petersen, R. J. Caselli, Z. K. Wszolek, E. Finger, C. Lippa, D. Lacomis, H. Stewart, D. W. Dickson, H. J. Kim, E. Rogaeva, E. Bigio, K. B. Boylan, J. P. Taylor, R. Rademakers, Neuron 2017, 95, 808, DOI: 10.1016/j.neuron.2017.07.025.

[120] A. E. Renton, E. Majounie, A. Waite, J. Simon-Sanchez, S. Rollinson, J. R. Gibbs, J. C. Schymick, H. Laaksovirta, J. C. van Swieten, L. Myllykangas, H. Kalimo, A. Paetau, Y. Abramzon, A. M. Remes, A. Kaganovich, S. W. Scholz, J. Duckworth, J. Ding, D. W. Harmer, D. G. Hernandez, J. O. Johnson, K. Mok, M. Ryten, D. Trabzuni, R. J. Guerreiro, R. W. Orrell, J. Neal, A. Murray, J. Pearson, I. E. Jansen, D. Sondervan, H. Seelaar, D. Blake, K. Young, N. Halliwell, J. B. Callister, G. Toulson, A. Richardson, A. Gerhard, J. Snowden, D. Mann, D. Neary, M. A. Nalls, T. Peuralinna, L. Jansson, V. M. Isoviita, A. L. Kaivorinne, M. Holtta-Vuori, E. Ikonen, R. Sulkava, M. Benatar, J. Wuu, A. Chio, G. Restagno, G. Borghero, M. Sabatelli, I. Consortium, D. Heckerman, E. Rogaeva, L. Zinman, J. D. Rothstein, M. Sendtner, C. Drepper, E. E. Eichler, C. Alkan, Z. Abdullaev, S. D. Pack, A. Dutra, E. Pak, J. Hardy, A. Singleton, N. M. Williams, P. Heutink, S. Pickering-Brown, H. R. Morris, P. J. Tienari, B. J. Traynor, Neuron 2011, 72, 257, DOI: 10.1016/j.neuron.2011.09.010.

[121] K. H. Lee, P. Zhang, H. J. Kim, D. M. Mitrea, M. Sarkar, B. D. Freibaum, J. Cika, M. Coughlin, J. Messing, A. Molliex, B. A. Maxwell, N. C. Kim, J. Temirov, J. Moore, R. M. Kolaitis, T. I. Shaw, B. Bai, J. Peng, R. W. Kriwacki, J. P. Taylor, Cell 2016, 167, 774, DOI: 10.1016/j.cell.2016.10.002.

[122] B. Khosravi, H. Hartmann, S. May, C. Mohl, H. Ederle, M. Michaelsen, M. H. Schludi, D. Dormann, D. Edbauer, Hum. Mol. Genet. 2017, 26, 790, DOI: $10.1093 / \mathrm{hmg} / \mathrm{ddw} 432$.

[123] H. A. Lashuel, C. R. Overk, A. Oueslati, E. Masliah, Nat. Rev. Neurosci. 2013, 14, 38, DOI: $10.1038 / \mathrm{nrn} 3406$.

[124] T. Nonaka, M. Masuda-Suzukake, T. Arai, Y. Hasegawa, H. Akatsu, T. Obi, M. Yoshida, S. Murayama, D. M. Mann, H. Akiyama, M. Hasegawa, Cell Rep. 2013, 4, 124, DOI: 10.1016/j.celrep.2013.06.007.

[125] S. Porta, Y. Xu, C. R. Restrepo, L. K. Kwong, B. Zhang, H. J. Brown, E. B. Lee, J. Q. Trojanowski, V. M. Lee, Nat. Commun. 2018, 9, 4220, DOI: 10.1038/s41467-018-06548-9.

[126] M. Polymenidou, D. W. Cleveland, Cell 2011, 147, 498, DOI: 10.1016/j. cell.2011.10.011. 